NBER WORKING PAPER SERIES

\title{
A HEAD-TO-HEAD COMPARISON OF AUGMENTED WEALTH IN GERMANY AND THE UNITED STATES
}

\author{
Timm Bönke \\ Markus Grabka \\ Carsten Schröder \\ Edward N. Wolff \\ Working Paper 23244 \\ http://www.nber.org/papers/w23244 \\ NATIONAL BUREAU OF ECONOMIC RESEARCH \\ 1050 Massachusetts Avenue \\ Cambridge, MA 02138 \\ March 2017
}

Markus M. Grabka, Carsten Schröder, and Edward N. Wolff thank the Deutsche Forschungsgemeinschaft under contract GR 3239/4-1 for financial support for our research. We also like to thank Tobias Schmidt and participants in the 2016 conference of the International Association for Research in Income and Wealth (IARIW) in Dresden for valuable comments, and Deborah Anne Bowen for editing the paper. The views expressed herein are those of the author and do not necessarily reflect the views of the National Bureau of Economic Research.

NBER working papers are circulated for discussion and comment purposes. They have not been peer-reviewed or been subject to the review by the NBER Board of Directors that accompanies official NBER publications.

(C) 2017 by Timm Bönke, Markus Grabka, Carsten Schröder, and Edward N. Wolff. All rights reserved. Short sections of text, not to exceed two paragraphs, may be quoted without explicit permission provided that full credit, including $\odot$ notice, is given to the source. 
A Head-to-Head Comparison of Augmented Wealth in Germany and the United States Timm Bönke, Markus Grabka, Carsten Schröder, and Edward N. Wolff NBER Working Paper No. 23244

March 2017

JEL No. D31,H55,J32

\section{ABSTRACT}

We provide levels of, compositions of, and inequalities in household augmented wealth - defined as the sum of net worth and pension wealth - for two countries: the United States and Germany. Pension wealth makes up a considerable portion of household wealth: about $48 \%$ in the United States and 61\%in Germany. The higher share in Germany narrows the wealth gap between the two countries: While average net worth in the United States (US\$337,000 in 2013) is about 1.8 times higher than in Germany, augmented wealth (US\$651,000) is only 1.4 times higher. Further, the inclusion of pension wealth in household wealth reduces the Gini coefficient from 0.892 to 0.701 in the United States and from 0.765 to 0.511 in Germany.

Timm Bönke

Free University Berlin

Boltzmannstraße 20,b Room 305

14195 Berlin

timm.boenke@fu-berlin.de

Markus Grabka

SOEP at DIW Berlin

mgrabka@diw.de
Carsten Schröder

German Institute for Economic Research

(DIW Berlin)

CSchroeder@diw.de

Edward N. Wolff

Department of Economics

New York University

19 W. 4th Street, 6th Floor

New York, NY 10012

and NBER

edward.wolff@nyu.edu 


\section{Introduction}

Economists argue that the recent rise in inequality in many advanced economies is one of the most serious problems facing the world today (Acemoglu and Robinson, 2012, Ostry et al. 2014, Stiglitz 2012). This is for economic, societal, as well as political reasons. Economically, high inequality may harm the economy because credit rationing prevents the poor from investing in education and weakens innovations. Societally, high inequality may reduce social cohesion because people are less likely to trust each other and, therefore, reduce their community involvement. Politically, high inequality may lead to the emergence of economic elites who use their power to (re)shape the political system and engage in rent-seeking activities, further widening the economic and social disparities.

Most of the academic, political, and public debates have focused on inequalities in income, addressing the inter-temporal evolution of income inequality, differences across countries, the redistributive effects of tax-benefit systems, income concentration at the top of the distribution, the causes and driving forces behind income inequalities, and related issues. Wealth inequalities, on the other hand, have received much less attention, and rigorous crosscountry comparisons based on comparable data are scarce. ${ }^{1}$ This is not for lack of interest: what is lacking are data. A recent data initiative by the European Central Bank aims at closing the data gap with its Household Finance and Consumption Survey (HFCS; see Eurosystem (2009, 2013) for an introduction), which has opened up new opportunities for empirical research. ${ }^{2}$

Most empirical analyses of wealth inequalities to date focus on four wealth aggregates: real assets, financial assets, debts, and the difference between assets and debts, net worth. Differences in levels of and inequalities in these aggregates miss an important component of household wealth positions: pension wealth, the discounted expected present value of future entitlements from public, occupational, and private pension schemes. Considering pension wealth is important because households in different countries make private savings decisions conditional on the country-specific characteristics of pension institutions: their coverage,

\footnotetext{
${ }^{1}$ Exceptions include Almås and Mogstad (2012), Azpitarte (2011, 2012), Bover (2010), Bover et al. (2016), Cowell et al. (2012), Davies et al. (2011), Gornick et al. (2009), Müller (2016), Paradowski and Flynn (2015), Sierminska and Bicáková (2007), Sierminska and Takhtamanova (2006), and Wolff and Zacharias (2009).

${ }^{2}$ Recent HFCS-based comparative wealth studies are Kaas et al. (2015) and Cowell et al. (2016).
} 
generosity, (expected future) financial stability, etc. In particular, many empirical studies find that (public) pension wealth serves as a substitute for other forms of private savings. ${ }^{3}$ Higher net worth in a country A than in country B may indicate higher propensities to consume in the former. Yet if pension institutions are more generous in the latter, the opposite may be true. A comprehensive measure that considers pension wealth in addition to real and financial assets is augmented wealth (Wolff, 2015a, Wolff, 2015b; Bönke et al., 2016). Pension wealth is a substitute for other assets, as it a source of future income but not a perfect substitute: It is not under the direct control of the insurant and cannot be marketed directly (see Wolff, 2015b).

As far as we are aware, this study represents the first systematic "head-to-head" comparison of household net worth, pension wealth (including survivor pensions), and augmented wealth for two countries, the United States and Germany. The comparison relies on a harmonized database constructed from recent waves of the Survey of Consumer Finances (SCF) and the Socio-Economic Panel (SOEP), ${ }^{4}$ and encompasses both the retired and non-retired population. Our empirical analysis addresses the following dimensions: (a) wealth levels and composition; (b) wealth inequalities (including an inequality comparison by sources); and (c) age trajectories of wealth accumulation.

Our results are as follows: The inclusion of pension wealth adds about $48 \%$ to average net worth in the United States and $61 \%$ in Germany. This reduces the wealth gap between the two countries: While the ratio of average net worth is about 1.8 in favor of the United States (average for United States: US\$337,000; Germany: US\$182,000), it is considerably lower, 1.4, for augmented wealth (average for United States: US\$651,000; Germany: US\$473,000). The addition of pension wealth also reduces measured wealth inequalities: In the United States, the Gini coefficient drops from 0.892 for net worth to 0.701 for augmented wealth; in Germany from 0.765 to 0.511 .

The remainder of the paper is organized as follows. Section 2 provides a brief review of the empirical literature on augmented wealth. Section 3 discusses relevant aspects of the pension

\footnotetext{
${ }^{3}$ For influential papers, see Attanasio and Brugiavini (2003), Bosworth and Burtless (2004), Browning and Lusardi (1996), Cagetti (2003), Gale (1998), and Samwick (2000).

${ }^{4}$ The crucial challenge of such a comparison is the lack of information on (public) pension wealth in standard wealth databases as the Luxembourg Wealth Study (see Sierminska et al., 2006) or the European Central Bank (Eurosystem Household Finance and Consumption Survey, HFCS).
} 
systems in Germany and the United States. Section 4 details the methods and data underlying the empirical analysis. Section 5 presents comparative results on German and US wealth distributions. Concluding remarks are given in Section 6.

\section{Literature review on studies of augmented wealth}

The role of social security systems in individual and household decisions has received considerable attention in economic research focusing on the interplay between social security and private wealth (e.g., levels and compositions of individual and household wealth portfolios), wealth accumulation (crowding-in or crowding-out effects of social security), and retirement decisions. Case studies that explicitly address social security wealth in analyses of private wealth and portfolio compositions, all for the United States, are Moffitt (1984), Gustman et al. (1997), Gustman et al. (2011) and Wolff (2014). The role of social security in private savings decisions and wealth accumulation has been addressed empirically, for example, in Boyle and Murray (1979) and Dicks-Mireaux and King (1984) for Canada, Leimer and Lesnoy (1982), Gullason et al. (1993) and Kennickel and Suden (1997) for the United States, and Börsch-Supan et al. (2008) for Germany.

The empirical literature on wealth inequalities that explicitly addresses social security wealth in a broad concept of (augmented) wealth is very limited, and cross-country comparisons based on harmonized data are scarce. The first study in this vein, by Wolff and Marley (1989), uses data from 1962 to 1983 to study inter-temporal changes in the level of concentration at the top of the US wealth distribution, thus explicitly investigating the role of expected social security wealth. Since their pioneering work, wealth inequalities and the role of social security wealth have been empirically addressed in a number of case studies. For the United States, Jianakoplos and Menchnik (1997) study the evolution of wealth mobility at a mean age of 45-49 by looking at transitions across quintiles using data from 1966 and 1981. Wolff (2005) focuses on the inequality-reducing effect if retirement wealth is considered as another component of household wealth (in addition to net worth wealth) before and after a major retirement reform in the United States that meant a considerable decline in traditional defined benefit pension plans and rise in defined contribution pensions. Wolff (2014) investigates wealth trends from 
1989 to 2010 by comparing wealth levels, and inequality for different wealth aggregates, namely net worth, private pension wealth, social security pension wealth, and finally augmented wealth.

For Canada, Shamsuddin (2001) shows that social security wealth constitutes $47 \%$ of augmented wealth and that its inclusion in household wealth leads to a marked decline in wealth inequalities. Mazzaferro and Toso (2005) use six cross-sections of the Bank of Italy Survey of Income and Wealth to investigate the composition and distribution of augmented wealth in Italy over the period 1991 to 2002. Roine and Waldenström (2009) study the wealth concentration in Sweden over 130 years up to the present using estate and wealth tax data, foreign and domestic family firm wealth, and pension wealth estimates since 1978.

Using Finnish survey and pension register data from 2004, Maunu (2010) studies how the inclusion of pension wealth alters the wealth distribution, considering the non-retired population over 44 years of age. Comparable papers for Germany that also combine survey and administrative data and address the inequality-reducing effect of including pension wealth in standard wealth measures are Frick and Grabka (2010) and (2013).

Perhaps the closest paper to ours is that of Bönke et al. (2016), who quantify levels and distributions of net worth and an augmented wealth concept that also considers individual pension entitlements from the three pillars of the German pension system (social security, occupational, and private pensions). In contrast to Frick and Grabka (2010, 2013), Bönke et al. (2016) rely exclusively on survey data - the German SOEP - to show that pension wealth is an important component of individual wealth in Germany and that its inclusion in the individual wealth distribution implies a sizeable reduction in measured inequality.

We build on the methods outlined in Bönke et al. (2016), which built on the previous literature by providing: (a) a nationwide analysis of wealth inequalities that is not restricted to particular sub-populations (e.g., the retired or married couples); (b) a comprehensive analysis of household portfolios and an inequality decomposition of augmented wealth by wealth aggregates; $(c)$ the computation of pension wealth using the accrual value. The accrual method is advantageous to the ongoing concern treatment as it requires less information on future 
labor force participation, income levels, and retirement decisions, and, like net worth, reflects the current (not future potential) level of material well-being.

The present paper differs from Bönke et al. (2016) in several respects. First, our paper is comparative: Building on harmonized data and comparable wealth concepts, we investigate standard and augmented wealth distributions for two countries with rather different social security systems: Germany and the United States. To our knowledge, only two papers to date have provided a comparative analysis of augmented wealth: Wolff (1996) for the United States ${ }^{5}$ and Canada, and Frick and Headey (2009) for Australia and Germany. ${ }^{6}$ Second, Bönke et al. (2016) provide wealth figures at the individual level, whereas we provide these figures at the household level. The household-level concept reflects that households usually pool resources. ${ }^{7}$ Measuring a household's expected pension entitlements requires the assumption that the household members do not separate their resources later in life.

Third, our pension wealth measure is broader than that in Bönke et al. (2016), as we also incorporate actual and expected survivor pension entitlements. To our knowledge, this is a unique feature of the present work compared to all previous studies on wealth inequalities.

\section{Pension institutions in the United States and Germany}

Both pension systems in the United States and Germany are comprised of a social security, an occupational (including a government employee pension scheme), and a private component. Beyond this common feature, the two countries' systems differ markedly with respect to generosity, coverage, attainment of entitlements, type of financing, etc. Below we provide a short description of the pension institutions in both countries.

\footnotetext{
${ }^{5}$ Wolff (1996) gives empirical estimates of the share of augmented wealth in the United States and United Kingdom for the richest $1 \%$ at three points in time $(1972,1976,1981)$, but not a description of the entire wealth distribution.

${ }^{6}$ The study by Frick and Headey (2009) considers the retired population only.

${ }^{7}$ For a discussion of the comparative advantages of wealth measurement at the household and individual level, see also Bönke et al. (2016). In the Survey of Consumer Finances, the observation unit is the household, and individual-level wealth holdings are not reported.
} 


\subsection{Pensions in the United States}

\subsubsection{Social security pensions}

Social security pensions in the United States are strictly earnings-related and mandatory for employees. The retirement (or "old age") benefit is determined by formula. The system has the following three key features: First, coverage is assigned based on whether the individual expects to receive a social security pension and on whether the individual was salaried or selfemployed. In 2013, 98\% of all workers were eligible for a social security pension. Second, the person's Average Indexed Monthly Earnings (AIME) is computed on the basis of his or her earnings history. Rules in 2013 stipulated that for eligibility, a worker must work a minimum of 40 quarters at a minimum earnings level in a covered job. The worker's AIME is then based on the highest 140 quarters of earnings over the lifetime of the worker. Third, the person's Primary Insurance Amount (PIA) is derived from AIME.

In contrast to Germany, the formula is redistributive in that lower-earning workers receive a higher percentage of their AIME in the computation of their PIA than higher-earning workers. For example, for 2014, the PIA is calculated by taking $90 \%$ of AIME under US\$816, 32\% of AIME between US\$816 and US\$4,917, and 15\% of AIME greater than US\$4,917.

The survivor benefit applies only to married couples. This is determined by the higher of two values: (1) the deceased spouse's PIA and (2) the individual's own PIA. The spousal benefit likewise applies only to married couples. It is determined by the higher of (1) $50 \%$ of the spouse's PIA and (2) the individual's own PIA. For the survivor benefit, there are three possibilities:

1. One spouse (say the husband) worked over his lifetime but the wife did not. Then, the survivor benefit for the wife is equal to the husband's benefit.

2. Both spouses worked but the wife earned less than the husband. When the husband dies, the wife's survivor benefit is set equal to the husband's benefit. If there were no survivor benefit, the wife would be entitled to her own PIA. So the true value of the survivor benefit

\footnotetext{
${ }^{8}$ There is a minimum social security pension benefit established by law. The disability benefit is determined in exactly the same way as the social security pension retirement benefit. The worker's AIME is computed up to the time of disability and this value is then converted into the corresponding PIA amount using the same formula as for the retirement benefit.
} 
in this case (and the one we use) is equal to the difference between the husband's benefit and the wife's own PIA.

3. Both spouses work but the wife has a higher PIA than the husband. When the husband dies, the wife effectively receives no survivor benefit since she is already entitled to her own PIA.

\subsubsection{Occupational and private pension schemes}

Occupational pension plans are either defined benefit (DB) or defined contribution pension schemes (DC). Pensions for government employees (federal, state, or local) are in principle a special form of occupational pensions. ${ }^{9}$

Defined contribution plans are the dominant form of occupational pension plans in the private sector. In 2010, almost $60 \%$ of those between 47 and 64 years of age held DC pension plans as opposed to 30\% DB pension plans (Wolff 2014). They are employer-sponsored with an individual account for each participant, and contributions may stem from employee salary deferrals, employer contributions, or employer matching contributions (Internal Revenue Code Section 414/415). Examples of occupational pension plans are employer-sponsored 401(k) and profitsharing plans, most of which enjoy tax-favored treatment.

Defined benefit plans define the payment received upon retirement and encompass all pension plans that are not defined contribution and therefore do not have individual accounts (hence including hybrid pension plans such as cash balance plans and pension equity plans). Typically, DB plans offered by large employers are final average pay plans. In this case, the monthly benefit is equal to the number of years worked multiplied by the member's salary at retirement multiplied by a factor known as the accrual rate. For unmarried participants, benefits are usually payable as a Single Life Annuity (SLA); married participants receive a Qualified Joint and Survivor Annuity (QJSA).

Pure private pension plans may be either DC or DB pension plans. Typical examples are Individual Retirement Accounts (IRAs), Keogh or HR10 plans, solo 401(k) plans and Roth IRAs. These are

\footnotetext{
${ }^{9}$ Government employees are usually eligible for civil servant pensions (also known as Public Employee Retirement Systems, PERS). The majority of these are defined benefit pension plans, but some local governments offer defined contribution pension plans. Entitlement calculation in principle follows the basic rules used for occupational DB pension schemes.
} 
retirement plans mainly for the self-employed or small businesses. As it is the case for IRAs or 401(k) plans, the funds can be invested in stocks, bonds, mutual fund, etc.

\subsubsection{Generosity of pensions in the United States}

Table 1a shows a breakdown of the number of recipients and median pension amounts in 2014 for individuals aged 65 and older. According to the US Social Security Administration, almost 46 million individuals receive social security benefits with a median monthly pension of US\$1,480. ${ }^{10}$ Employer pensions also play an important role. Roughly $44 \%$ of the elderly receive employer pensions. Here, one can differentiate between government employee pensions and private pensions. More than 5.3 million individuals receive the former, and the median monthly amount is US\$1,453. More than $15 \%$ of the elderly have pension claims from a government pension scheme. Roughly 13 million receive private pensions and annuities with a median monthly amount of US\$833. However, these figures are not divided into DC and DB pension plans. ${ }^{11}$

Table 1a. Pensions by pension scheme (persons 65 years and older) in the United States, 2014

\begin{tabular}{|c|c|c|c|c|}
\hline Pension scheme & $\begin{array}{l}\text { Number of } \\
\text { recipients (in } \\
\text { thousands) }\end{array}$ & $\begin{array}{l}\text { Median } \\
\text { pension } \\
\text { (in } 2014 \text { US\$/ } \\
\text { month) }\end{array}$ & $\begin{array}{l}\text { Share of } \\
\text { recipients } \\
\text { (in \%) }\end{array}$ & $\begin{array}{l}\text { Relative to total } \\
\text { money income } \\
\quad \text { (in \%) }\end{array}$ \\
\hline Retirement benefits & & & 87.4 & 54.1 \\
\hline Social Security benefits & 45,994 & 1,480 & 84.2 & 33.2 \\
\hline Employer pensions & 15,174 & 1,200 & 43,8 & 20.9 \\
\hline $\begin{array}{l}\text { Government employee } \\
\text { pension }\end{array}$ & 5,374 & 1,453 & 15.8 & 8.1 \\
\hline $\begin{array}{l}\text { Private pensions or } \\
\text { annuity }\end{array}$ & 12,931 & 833 & 37.4 & 12.8 \\
\hline $\begin{array}{l}\text { Total money income (earnings, } \\
\text { pensions, assets, cash transfers, } \\
\text { etc.) }\end{array}$ & & 2,516 & 100.0 & 100.0 \\
\hline
\end{tabular}

Source: Social Security Administration (2016): Income of the Population 55 or Older, 2014. SSA Publication No. 1311871 Released: April 2016.

Employer pensions include pensions from railroad retirement, government employee pensions, and private pensions and annuities. Government employee pensions include payments from the federal government (civil service), military, and state or local governments. Private pensions and annuities include payments from

\footnotetext{
${ }^{10}$ A further differentiation of social security pensions can be found in Table A1.

${ }^{11}$ Figures provided by the OECD (2008) suggest that approximately $61 \%$ of private-sector workers have access to company-sponsored pension plans, and that $20 \%$ of these workers have access to DB plans and $55 \%$ to DC plans.
} 
companies or unions, annuities or paid-up insurance policies, individual retirement accounts (IRAs), Keogh, or 401(k) payments.

\subsection{Pensions in Germany}

\subsubsection{Statutory social security pensions}

Mandatory statutory pension scheme for dependent employees

In 2014 , about $78 \%$ (or 36.1 million) of the German working-age population (20-65 years) are insured through the social security pension scheme, the "statutory pension insurance" (Gesetzliche Rentenversicherung) (DRV-Bund 2015). An individual is vested in their pension plan after having contributed for five years, or 60 months. ${ }^{12}$ Most importantly for the determination of statutory pension entitlements is the "equivalence principle," which establishes a close relation between the sum of earnings subject to compulsory insurance during working life and pension entitlement after retirement. ${ }^{13}$ Several types of statutory pensions are granted to insurants, with regular old-age pensions and pensions for the long-term insured being the most frequent types. $^{14}$

Besides the pension of the insurant, survivor pensions are granted to widows, widowers, and orphans. ${ }^{15}$ The level of a widow(er) pension depends on the actual pension of the deceased partner as well as the financial situation of the widow(er). ${ }^{16}$ Widow(er) pensions in the statutory pension scheme for dependent employees are determined based on the following basic rules:

\footnotetext{
${ }^{12}$ The legal framework is Book 6 of the Social Security Code (SSC VI). According to §§ 50-53 SSC VI, the social security pension scheme encompasses several specific sub-schemes for special occupational groups, including the miners' association (Knappschaft), seamen's insurance association (Seekasse), and the agriculture pension scheme (Landwirtschaftliche Alterskasse).

${ }^{13}$ The actual pension entitlement is defined by the "pension formula" detailed in SSC VI, Section 4. Pension entitlements may also be accrued during non-contribution periods: (i) sickness, rehabilitation, studies or higher education, etc. (Anrechnungszeiten); (ii) military service or detention due to political reasons (Ersatzzeiten); and (iii) child-raising or care for family members (Beruecksichtigungszeiten).

${ }_{14}$ Other pension types include reduced-earnings capacity pensions, pensions for the long-term unemployed, disability pensions, and special pensions for women. For further details on the statutory pension insurance in Germany, see Bönke et al. (2016).

${ }^{15}$ In 2012, about 4.78 million widow pensions and 0.574 million widower pensions were granted (BMAS 2012a).

${ }^{16}$ We assume that the surviving partner is entitled to a "large" widow(er) pension (see above). The widow(er) pension is reduced if the surviving partner has his or her own income. If her/his net income exceeds a monthly basic allowance of $€ 803.88$ in Germany's "old" (former West German) and $€ 756.62$ in its "new" (former East German) states in 2016 , the survivor pension is reduced by $40 \%$ of the difference between the net income of the surviving partner and the allowance.
} 
1. The marriage must have lasted for at least 12 months.

2. A widow(er) pension is granted if the deceased partner was insured for at least five years.

3. A "large" widower pension is granted if the widow(er) is age 47 or above, has a reduced earnings capacity, or if children below age 18 are living in the household. A "small" widow(er) pension is a temporary transfer for a widow(er) of working age.

\section{Entitlements from compulsory pension schemes of liberal professional associations}

The liberal professions ${ }^{17}$ are not covered by the mandatory statutory pension scheme for dependent employees but by 85 independent pension schemes, each of which have their own, highly individual rules. In 2014, about 1.4 million persons had entitlements from the liberal professions pension scheme (ABV 2016). Like the mandatory statutory pension scheme, this scheme provides old-age pensions, disability benefits, and survivors' benefits.

\subsubsection{Occupational and private pension schemes}

Occupational pension schemes are granted by a company to its employees, and comprise both DB and DC pensions, with highly individual contributions and benefit rules. ${ }^{18}$ About 56\% (14.1 out of 25 million) of compulsorily insured employees aged 25 to 65 in 2011 were covered under these schemes (BMAS 2012b). The basic regulations pertaining to survivor pensions in occupational pension plans ${ }^{19}$ are very similar to those in the statutory pension plans for employees. In line with the rules of the statutory pension system for employees, the widow(er) pension is reduced if the surviving partner has his or her own income.

The mandatory pension scheme for civil servants is unique to the German system. Civil servant pensions fall into the category of DB schemes, and for consistency with the US pension system, we assign them to the category of occupational pension plans. In the spirit of the equivalence principle, civil servant pensions primarily depend on the overall tenure and average salaries in the last position that a civil servant held for at least two years. In 2011, roughly 2.9 million

\footnotetext{
17 Members of special professional associations (Berufskammern) are, e.g., architects, chartered accountants, dentists, lawyers, notaries, pharmacists, physicians, and psychological psychotherapists.

${ }^{18}$ There exist at least five different company pension plans in Germany, starting with direct benefit plans, support funds (Unterstützungskasse), direct insurance (Direktversicherung), staff pension funds (Pensionskasse), and pension funds (Pensionsfonds), each with slightly different financing rules and benefit levels.

${ }^{19}$ Due to data limitations and for reasons of consistency, we again refrain from modeling orphan pensions.
} 
persons had entitlements from the civil servant pension scheme. For each year of full-time service, a civil servant collects 0.0179375 replacement points, with the regular maximum replacement rate being limited to 0.7175 . The annual pension entitlement for civil servants is the product of the replacement rate times the average annual salary. ${ }^{20}$ Survivor pensions by and large follow the basic rules for social security pensions (for further details, see appendix).

Private pension savings plans in Germany are comprised not only of standard non-subsidized life insurance and related types of financial products but most importantly of subsidized private pension plans. For the latter, financial aid and tax subsidies are granted to encourage private saving for retirement purposes. In 2002, the "Riester" and 2005 the "Rürup" pension saving programs were introduced, which in principle follow the same logic as the IRA or 401k in the United States. About 15 million people have signed a Riester pension contract, and another approximately 2 million a Rürup pension contract.

\subsubsection{Generosity of the German pension system}

For the retired population aged 65 or older, average monthly pensions vary widely in Germany. By far the most important scheme is the statutory pension insurance, which covers $90 \%$ of the retired population and grants, on average, a gross monthly payment of US\$1,197 (Table 1). In contrast, only $5 \%$ of the population is entitled to civil servant pensions, with a mean value of US\$3,649. One key reason for the higher average pension levels of civil servants is that they usually have a fairly uninterrupted work history, without unemployment spells, as well as higher educational qualifications. Additionally, the replacement rates under the civil servant pension scheme are more generous than under the statutory pension scheme. Retirees who are covered by one of the liberal profession schemes also enjoy a relatively high monthly pension, about US\$2,877 on average. Company pensions are employer-dependent and complement the statutory pensions. Thus, company pensions are, on average, considerably smaller than pensions in the other schemes. One can differentiate between company pensions in the private and public sector. In the private sector, the mean pension amounts to about US\$660, and $15 \%$

\footnotetext{
${ }^{20}$ If an individual receives a civil servant pension in addition to a statutory pension, particular deduction rules apply.
} 
of the retired population have an entitlement; in the public sector, the respective share is $10 \%$ and the monthly pension amounts to US\$424.

Table $1 \mathrm{~b}$ also provides information about survivor pensions for females 65 years and older. Again, the majority of female survivor pensioners receive pension from the statutory pension insurance, with a mean gross amount of US\$949/month. Similarly to the above findings, the highest pension is granted under the civil servant pension system to survivors, with a mean pension of US\$1,916. The incidence and average level of survivor pensions from the other systems are noticeably lower.

Table 1b. Pension by pension scheme (retired or widowed 65 years and older) in Germany, 2011

\begin{tabular}{|c|c|c|c|c|}
\hline Pension scheme & $\begin{array}{c}\text { Mean gross } \\
\text { pension } \\
\text { (in } 2013 \text { PPP } \\
\text { US\$/ month) }\end{array}$ & $\begin{array}{l}\text { Share of } \\
\text { recipients } \\
\text { (in \%) }\end{array}$ & $\begin{array}{c}\text { Mean gross } \\
\text { pension } \\
\text { (in } 2013 \text { PPP } \\
\text { US\$/ month) }\end{array}$ & $\begin{array}{l}\text { Share of } \\
\text { recipients } \\
\text { (in \%) }\end{array}$ \\
\hline & \multicolumn{2}{|c|}{ Own entitlement } & \multicolumn{2}{|c|}{ Female survivor pensions ${ }^{2}$} \\
\hline Statutory pension & 1,197 & 90 & 949 & 89 \\
\hline Civil servant & 3,649 & 5 & 1,916 & 8 \\
\hline Liberal professions & 2,877 & 1 & 1206 & 1 \\
\hline \multicolumn{5}{|l|}{ Company pensions } \\
\hline - private sector & 660 & 15 & 401 & 13 \\
\hline - public sector (VBL)) & 424 & 10 & 333 & 7 \\
\hline
\end{tabular}

Note. To derive PPP-adjusted US\$ in 2013, EUR amounts are multiplied by $1.02 \times 1.015 / 0.77$. ${ }^{1}$ Relative to all retired individuals living in Germany 65 year and older.

${ }^{2}$ Reliable information for male survivor pensioners is not available. However, only $6 \%$ of males age 65 and older are receiving GRV survivor pensions. Source: BMAS (2012a: 82). Shares add up to more than $100 \%$ because individuals can have multiple pensions.

\section{Data and definitions of wealth aggregates}

\subsection{German and US data sources}

The database used in the present study for Germany is the Socio-Economic Panel (SOEP) study. SOEP is an ongoing longitudinal survey of approximately 21,000 adult respondents, conducted annually since 1984 (see Wagner et al., 2007). SOEP consists of a number of sub-samples, including several random samples (drawn in different survey years) and also migrant and highincome samples. Information about private wealth was surveyed four times, in 1988, 2002, 2007, 
and $2012 .^{21}$ In contrast to other wealth surveys, the SOEP asks each adult respondent to provide information about her/his individual assets and debts. ${ }^{22}$ However, the individual wealth information is aggregated in the present study at the household level to obtain information comparable to that surveyed in the SCF. ${ }^{23}$

Our computations rely on SOEP respondents in private households who participated in the 2012 and 2013 waves and who were aged 18 or older in 2013. The two-year participation restriction is imposed because standard wealth variables are collected every five years, most recently in the 2012 wave (with asset values for the interview month), while current pension entitlements were collected in 2013 (retrospectively for the previous year). We exclude observations lacking valid information. ${ }^{24}$ This leaves a sample of 8,546 households, representing a total weighted number of about 38.7 million households.

The data source for the United States is the 2013 Survey of Consumer Finances (SCF) conducted by the Federal Reserve Board. Each survey consists of a core representative household sample combined with a high-income supplement (for more information about the sampling process, see Kennickell, 2008). The population used in the analysis consists of individuals at least 18 years of age in 2013, and all wealth information refers to 2013.

\subsection{Comparability of data sources}

An important difference between the SCF and SOEP is the over-sampling of top wealth holders in SCF and high-income households in SOEP. Since net income does not correlate perfectly with wealth, and the income threshold is relatively low, we would expect that the SCF better describes the wealth distribution at the very top.

\footnotetext{
${ }^{21}$ Real and financial assets include property wealth, financial assets, business assets, private pension entitlements, building-loan contracts, collectables, and outstanding debt (from property or consumer credits). See, for documentation of the SOEP wealth information, Grabka and Westermeier (2015).

${ }^{22}$ A potential benefit of surveying wealth information at the individual level is higher accuracy compared to surveys that rely exclusively on the answers of the reference person. This is particularly true for multi-person households. A potential drawback of the individual approach is the higher probability of non-response.

${ }^{23}$ Wealth held by children is not surveyed in SOEP, but it can be assumed that this has only a negligible impact on overall wealth levels and inequality.

${ }^{24}$ In particular, we exclude Sample M (the migration sample) and Sample K, as respondents in these samples did not provide information on wealth in 2012. Additionally, we exclude all observations with individual weighting factors of zero. An appropriate weighting scheme is available in SOEP to account for these exclusions.
} 
In contrast to SOEP, the SCF makes use of specially edited individual income tax returns developed by the Statistics of Income Division (SOI) to over-sample wealthy households. This is known as the "list sample". In a first stage, observations in areas selected for the first stage of the area probability sample are selected, while in a second stage, the remaining cases are stratified using a model of wealth conditional on the variables in the SOI data. As a result, about $98 \%$ of the entire SCF sample with at least US\$5 million of net worth in 2004 consists of observations from the list sample (see Kennickell, 2008).

The different oversampling strategies have implications for the composition of the two samples at the very top of the wealth distribution. There was no household observed in SOEP in 2012 beyond a threshold of US\$50 million. However, billionaires also live in Germany, as documented by the Forbes List. In SCF, 216 households hold more than 50 million US\$, and the wealthiest household holds a net worth of more than US\$1.3 billion. This evidence supports our expectation above that SCF better describes the top wealth percentiles than SOEP. This might contribute to higher measured levels of and inequalities in wealth in the United States compared to Germany.

To get an impression of what the different sampling strategies imply for our results, Figure 1 shows the sensitivity of the inequality indices, the Gini and the half-squared coefficient of variation (GE2), to different trimming thresholds for net worth. The thresholds range from the 99.9th to the 99.0th percentile. For the Gini coefficient, the effects of different trimming thresholds are minor. For GE2, which is sensitive to changes at the top, particularly the trimming at the 99.9th percentile has a strong downward effect in the United States. At lower thresholds, the effect disappears. Irrespective of the threshold, observed inequalities are always higher in the United States. Based on this evidence, we decided to apply a trimming threshold of the 99.9th percentile based on the country-specific distributions of net worth (see also Figure A1 for the effect of trimming on mean and maxima of net worth). 


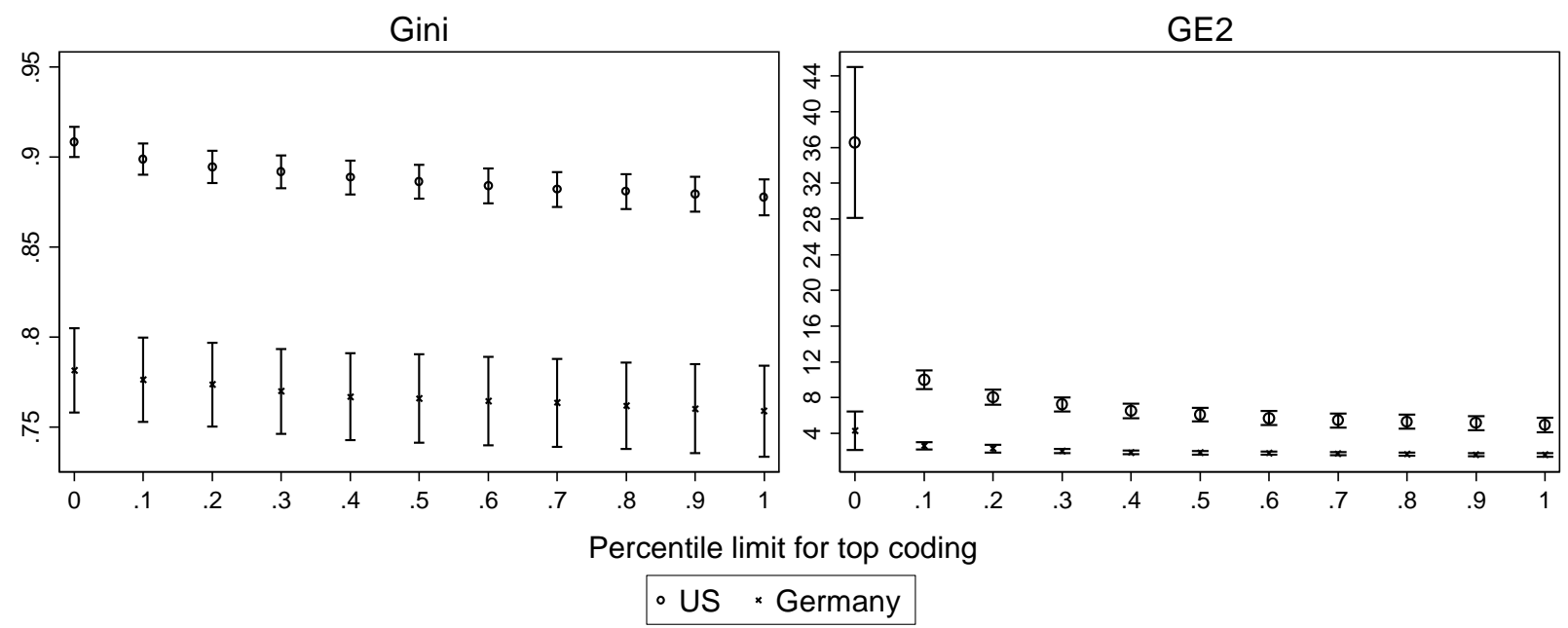

Note: All results based on multiple imputations, bootstrap 95\% confidence interval indicated by bars. Source: SCF 2013 and SOEP v30/v31, own calculations.

Figure 1. Effect of top trimming on net worth inequality using the Gini and GE2 coefficient

\subsection{Definitions of wealth aggregates}

Our empirical analysis focuses mainly on four wealth aggregates: net worth, social security pension wealth, private pension wealth (occupational, civil servant, and private pensions), and augmented wealth.

We define net worth (w10) as the current value of all marketable or fungible assets (total gross wealth) excluding the value of private pension plans minus current value of debts and without private pension plans. Private pension wealth is considered separately. Total gross wealth (w6) is the sum of owner-occupied property (w1); other real estate (w2); tangible assets (w3); business assets (w4); financial assets plus building society savings agreements (w5). Total debt is the sum of: mortgage debts for owner-occupied property (w7) or other real estate (w8); and consumer debts (w9). ${ }^{25}$ Pension wealth (w14) is the sum of social security pension wealth (w12), and occupational pensions (including civil servant pensions) ${ }^{26}$ and the value of private pension wealth (w13). Finally, augmented wealth (w15) is the sum of net worth and pension wealth. Table 2 provides a summary of the definitions.

\footnotetext{
${ }^{25}$ Credit card debts and educational loans are not explicitly surveyed in the German SOEP but are in the SCF.

${ }^{26}$ Unlike the SOEP, the SCF does not distinguish between defined benefit plans for public employees and those for private employees, so the two groups are aggregated into a single group in the computation of defined benefit pension wealth.
} 
In the empirical analysis, wealth is measured at the household level (no equalization by means of an equivalence scale or by capita in the households) in 2013-US\$and is PPP-adjusted (factor 0.7773 as provided by OECD). ${ }^{27}$

Table 2. Wealth aggregates

\begin{tabular}{ll} 
Acronym & Variable \\
\hline w1 & Owner-occupied property \\
w2 & Other real estate \\
w3 & Tangible assets (collectables such as jewelry, arts, etc.) \\
w4 & Business assets \\
w5 & Financial assets + building society savings agreements. \\
w6 & Total gross wealth (sum w1 to w5) \\
w7 & Mortgage debts - owner-occupied property \\
w8 & Mortgage debts - other real estate \\
w9 & Consumer debts \\
w10 & Net worth (w6 - (w7 + w8 + w9)) except private pension plans \\
w11 & Statutory pension wealth without survivor benefits \\
w11s & Statutory pension wealth from survivors benefits \\
w12 & Social security pension wealth (w11 + w11s) \\
w13 & Occupational and Private pension wealth \\
w14 & Pension wealth (w12 + w13) \\
w15 & Augmented wealth (w10 + w14) \\
\hline Note: ${ }^{1}$ This also includes equity in trust funds in the United States case, as well as the cash value of whole \\
life insurance plus the cash value of annuities (in response to the survey question "How much would you \\
receive if you cashed in these annuities?"). ${ }^{2}$ The accounting scheme differs in two ways from Wolff (2015): \\
First, net worth here excludes DC pension plans (the comparable variable in Wolff, 2015, is NWX). Second, \\
the term "pension wealth" here refers to the sum of DB pension wealth, DC pension wealth, and also \\
public pensions.
\end{tabular}

\subsection{Derivation of pension wealth}

Pension wealth is defined as the sum of social security pension wealth, civil servant pension wealth, company pension wealth, and private insurance contracts, including any survivor benefits. For particular pension components, the surrender value can be taken directly from the data. In Germany, this is the case for private insurance contracts, in the United States, for defined contribution (DC) plans, including Individual Retirement Accounts (IRAs), 401(K) plans,

\footnotetext{
${ }^{27}$ SOEP data from 2012 are converted to prices in 2013 with a consumer price index of 1.0015.
} 
and the like. If the surrender value is not provided, we take the gross present value of future expected pension entitlements accumulated until 2012. ${ }^{28}$ Gross means that pension entitlements are considered before taxes and social security contributions. ${ }^{29}$

All present values, $P V^{p}$, of future pensions from a particular pension scheme, $p=$ statutory, civil servant, company pensions, are adjusted for real interest rates and survival probabilities. $^{30}$ The present value is defined as,

$$
P V^{p}=\sum_{t=0}^{T} \frac{1}{(1+r)^{t}} \times \sum_{p} E_{t}^{p}
$$

with:

${ }^{28}$ The SCF questionnaire indicates how many pension plans husband and wife hold and what the expected (or current) pension benefit is. The SCF questionnaire also indicates whether the pension benefits remain fixed in nominal terms over time for a particular beneficiary or are indexed for inflation. A separate computation of private pension wealth is performed for each pension plan. For current workers, the procedure is more complex. The SCF provides detailed information on pension coverage among current workers, including the type of plan, the expected benefit at retirement or the formula used to determine the benefit amount (for example, a fixed percentage of the average of the last five year's earnings), the expected retirement age when the benefits are effective, the likely retirement age of the worker, and vesting requirements. Information is provided not only for each spouse's current job (or jobs) but for up to five past jobs as well. The respondent is also asked to indicate what his (or her) pension benefit will be, based on his or her work history to date. The accrual value of private pension wealth is then computed for each job stated by the respondent.

${ }^{29}$ Augmented wealth is an aggregate of several wealth components. For the interpretation of the level and distribution of augmented wealth, three aspects should be noted. First, financial wealth in the form of standard monetary deposits is not subject to taxes and social security contributions in Germany. However, when converting assets or real wealth into money, taxes may arise. The tax burden then depends on many unobserved tax-relevant characteristics (e.g., acquisition value, speculation and holding periods). Second, the current and the liquidation value of an insurance contract (e.g., of a life-risk insurance or private pension) may differ. This is due, for instance, to insurance fees or repayment of tax relief or allowances (i.e., subsidized private pension plans). Third, if a wealth aggregate is determined by the present value of a future income stream (e.g., statutory or company pension), the future incomes are subject to social security contributions and/or taxes. We refrain from an approximation of net present values, given that it requires numerous assumptions about the future income composition, future family status, etc. Thus, augmented wealth is comprised of wealth components that differ with respect to tax- and socialsecurity burdens. This implies that, de facto, the convertibility of the different components is limited, an issue which, for the aforementioned reasons, is not reflected in the subsequent analysis.

${ }^{30}$ In the case of the United States, official survival probabilities are provided by the US Center for Disease Control (CDC) up to and including age 99. The CDC provides survival probabilities by age, gender, and race (white versus African-American). African-American survival rates are systematically lower than the corresponding rates for whites. We use the racial breakdown in our calculation of US pension wealth. For Germany, the mortality rates differ by sex only. Due to lack of comparable data we only differentiate mortality rates by gender, birth year (and region of origin).

Few papers also empirically estimate differential mortality with respect to economic variables such as income or wealth. For studies dealing with the United States, see Chetty et al. (2016) or Attanasio and Hoynes (2000); for Germany see von Gaudecker and Scholz (2007). These studies rely on different methods and are not comparable. Delavande and Rohwedder (2011) undertake a comparison for both countries, but it relies on subjective assessments of survival probabilities. 
1. T: end of life, here the year in which the individual turns age 99.

2. $r$ : constant discount rate (here $2 \%){ }^{31}$.

3. $E_{t}^{p}$ : expected value of all individual pension entitlements in period $t$ from system $p$.

In a household, a retired person (including those with pensions for reduced earning capacity) receives the pension from period $t=0$ (year 2012) onward. A non-retired person receives the pension starting in a future period $t>0$, defined by the person's age and the official retirement age.

There are important differences between the United States and Germany in widow(er) pensions. In Germany, a widow(er) pension is granted to the surviving married partner. ${ }^{32}$ The central function of a widow(er) pension is to provide for the surviving partner in old age after the death of a partner, while orphans' pensions act as child support. In the United States, the insurant's partner may be eligible for his or her own pension depending on the partner's entitlements from retirement age onward, but no additional widow(er) pension is granted. This has implications for the computation of expected pension values. In the United States in general and for non-married individuals in Germany, the expected value of a type $p$ pension in period $t$ is,

$$
E_{t}^{p}=\sum_{i=1}^{I} d_{t, i}^{p} \times \operatorname{pension}_{t, i}^{p} \times \sigma_{t, i, g, c} .
$$

Here, $d_{t, i}^{p}$ is a dummy variable with value 1 if person $i$ is eligible for the pension in period $t$, pension $_{t, i}^{p}$ is her pension entitlement, and $\sigma_{t, i, c}$ is the probability that the person (gender $g$ from birth cohort, $c$ ) is still alive in $t$ (survival probability) up to age 99.

In Germany, because of widower pensions, we must differentiate the following states for married couples: ${ }^{33}$

1. Both partners are alive in $t$. Then each partner receives his/her own individual pension. The probability of the first state is the joint survival probability of the male $(m)$ and female partner $(f), \sigma_{t, i, m, c} \times \sigma_{t, i, f, c}$.

\footnotetext{
${ }^{31}$ For the impact of alternative interest rates on substantive findings, see Bönke et al. (2016), Table A1.

${ }^{32}$ Orphan pensions are also granted. However, our analysis deals with old-age pension entitlements, while orphan pensions act as temporary social assistance during education.

${ }^{33}$ Exemplary household survival rates for Germany are provided in Figure A1.
} 
2. The male partner is deceased but the female partner is alive. Then the male partner's pension entitlements are zero and the female partner receives her own pensions plus a widow pension (if eligible). The probability of the second state is, $\left(1-\sigma_{t, i, m, c}\right) \times \sigma_{t, i, f, c}$.

3. The female partner is deceased but the male partner is alive. Then the female partner's pension entitlements are zero and the male partner receives his own pensions plus a widower pension (if eligible). The probability of the third state is, $\sigma_{t, i, m, c} \times\left(1-\sigma_{t, i, f, c}\right)$.

The above procedure for determining the present value of current pension entitlements ${ }^{34}$ is based on the "accrual method" (see Wolff 2015). ${ }^{35}$ When interpreting the present values, it should be noted that entitlements from the liberal professions pension scheme are not included in present values for the non-retired population, but only for the retired.

\section{Empirical findings}

The subsequent comparative empirical analysis for the United States and Germany addresses three aspects: the level and composition of household wealth, wealth inequalities, and agewealth profiles.

\subsection{Wealth levels in the United States versus Germany}

Table 3 provides information on different wealth aggregates for the United States and Germany. At first glance, wealth levels differ substantially between the two countries. For net worth, the mean value of about US\$183,000 in Germany is only 54\% of the mean value in the United States, about US\$337,000. The gap for median net worth, however, is much smaller, and the median is even slightly higher in Germany: almost US\$50,000 compared to US\$40,000 in the United States. For the 75th percentile, we find a similar result: a small difference in favor of German households (about US\$231,000 versus US\$200,000 in the United States). In both

\footnotetext{
${ }^{34}$ Current entitlements are based on the biography until today. They do not include projected entitlements credited for employment periods in the future.

${ }^{35}$ The figures reported in Wolff (2015) rely mainly on the conventional "on-going concern" treatment. It is assumed in this that employees continue to work at their place of employment until their expected date of retirement. The value of pension wealth is estimated as of the date of expected retirement.
} 
countries, net worth for the 25th percentile is zero. These numbers suggest that net worth in the United States is more concentrated at the top of the distribution. It is not entirely clear to what extent the higher concentration is driven by the oversampling of top wealth holders in the SCF and/or the underrepresentation of high net worth individuals in SOEP (see Westermeier and Grabka, 2015).

We decompose pension wealth into two components: social security and the sum of occupational and private pension wealth. Due to the compulsory nature of social security pension contributions in both countries, about $95 \%$ of the total population holds social security pension wealth. In Germany, average social security pension wealth amounts to about US\$200,000, which is $25 \%$ higher than the value in the United States, about US\$161,000. Social security wealth can be divided further into own entitlements and wealth from survivor benefits. As expected, in both countries, about $90 \%$ of total social security wealth comes from own entitlements.

In both countries, about $60 \%$ of the population has entitlements from occupational and private pension schemes. However, mean values are 1.7 times higher in the United States, at US\$153,000 compared to only US\$90,000 in Germany.

There is also a substantial gap in levels for augmented wealth: The average US household possesses about US\$650,000, and thus 1.4 times the wealth of an average German household (about US\$473,000). This difference is mainly driven by the higher net worth of US households that belong to the top of the augmented wealth distribution. Up to the 75th percentile, households in Germany possess larger assets. For example, the 25th percentile value of augmented wealth is about US\$149,000 versus US\$86,000 in the United States. ${ }^{36}$

Table 3. Basic descriptive statistics by wealth aggregate

\footnotetext{
${ }^{36}$ There is no standard convention for whether wealth should be measured using equivalent weights. In this study, we implicitly assume an equivalence weight of 0 . However, an alternative procedure is to apply an equivalence weight of 1 (= household size). Basic descriptive statistics and inequality figures by wealth aggregate are provided in Table $A 3$ and Table A4.
} 


\begin{tabular}{|c|c|c|c|c|c|}
\hline Wealth aggregate & $\begin{array}{l}\text { Mean } \\
\text { (SE) }\end{array}$ & P25 & P50 & P75 & $\begin{array}{c}\text { Fraction }>0 \\
\text { (SE) }\end{array}$ \\
\hline \multicolumn{6}{|c|}{ United States } \\
\hline Net worth & $\begin{array}{c}336,636 \\
(5,765)\end{array}$ & 0 & 40,000 & 198,510 & $\begin{array}{l}73.07 \\
(0.28)\end{array}$ \\
\hline $\begin{array}{l}\text { Social security pension } \\
\text { wealth }\end{array}$ & $\begin{array}{c}161,475 \\
(906)\end{array}$ & 64,486 & 124,938 & 227,458 & $\begin{array}{l}96.49 \\
(0.13)\end{array}$ \\
\hline - own entitlements & $\begin{array}{c}149,263 \\
(837)\end{array}$ & 59,428 & 117,243 & 211,562 & $\begin{array}{l}96.49 \\
(0.13)\end{array}$ \\
\hline - survivor benefit & $\begin{array}{c}12,212 \\
(112)\end{array}$ & 0 & 3,471 & 18,960 & $\begin{array}{l}56.29 \\
(0.33)\end{array}$ \\
\hline $\begin{array}{l}\text { Occupational and } \\
\text { private pension wealth }\end{array}$ & $\begin{array}{c}153,351 \\
(2,310)\end{array}$ & 0 & 13,000 & 139,877 & $\begin{array}{l}61.69 \\
(0.32)\end{array}$ \\
\hline Augmented wealth & $\begin{array}{c}651,462 \\
(7,450)\end{array}$ & 85,989 & 246,531 & 607,288 & $\begin{array}{l}95.75 \\
(0.13)\end{array}$ \\
\hline \multicolumn{6}{|c|}{ Germany } \\
\hline Net worth & $\begin{array}{c}182,513 \\
(2,684)\end{array}$ & 0 & 49,623 & 231,139 & $\begin{array}{l}71.56 \\
(0.22)\end{array}$ \\
\hline $\begin{array}{l}\text { Social security pension } \\
\text { wealth }\end{array}$ & $\begin{array}{c}200,407 \\
(957)\end{array}$ & 68,257 & 162,540 & 295,027 & $\begin{array}{l}93.08 \\
(0.14)\end{array}$ \\
\hline - own entitlements & $\begin{array}{c}178,555 \\
(894)\end{array}$ & 57,508 & 141,150 & 264,181 & $\begin{array}{l}92.78 \\
(0.14)\end{array}$ \\
\hline - survivor benefit & $\begin{array}{c}21,853 \\
(270)\end{array}$ & 0 & 0 & 19,569 & $\begin{array}{l}27.48 \\
(0.22)\end{array}$ \\
\hline $\begin{array}{l}\text { Occupational and } \\
\text { private pension wealth }\end{array}$ & $\begin{array}{l}90,122 \\
(1,093)\end{array}$ & 0 & 13,059 & 78,801 & $\begin{array}{l}64.20 \\
(0.24)\end{array}$ \\
\hline Augmented wealth & $\begin{array}{c}473,043 \\
(2,997)\end{array}$ & 149,128 & 326,525 & 631,883 & $\begin{array}{l}98.30 \\
(0.07)\end{array}$ \\
\hline
\end{tabular}

Note: The sample is top-trimmed at the 99.9th percentile. All results are based on multiple imputations; bootstrap standard errors accounting for multiple imputations are shown in parentheses. Nonlinear estimates (P25, p50, P75) are based on first imputation only. Source: authors' calculations from the SCF 2013 and SOEP v30/v31.

Details on household portfolios including different kinds of debt are detailed in Table 4. The table is subdivided into three panels. The top panel provides the composition of household total gross wealth. The second panel provides the composition of household debt. The third panel provides debt-to-wealth and debt-to-income ratios.

With regard to the composition of household total gross wealth, the most important difference between the two countries pertains to owner-occupied property. In Germany, this 
wealth component contributes nearly $60 \%$ to total gross wealth, and only about $40 \%$ in the United States. Important differences also relate to the relative contributions of business assets and also to financial assets and building society savings agreements. Business assets contribute only about $7 \%$ to total gross wealth in Germany and almost $19 \%$ in the United States. For financial assets and building society savings agreements, the respective numbers are $28 \%$ in the United States and $17 \%$ in Germany.

Concerning debt, total household debts in the United States is, at about US\$91,000 on average, 2.5 times higher than in Germany (US\$36,000). Mortgage debt on owner-occupied property makes up the largest relative portion in both countries: $74 \%$ in the United States and $61 \%$ in Germany. Debt ratios in the United States are also higher than in Germany, with respect to both income and net worth (see panel 3 of Table 4). While the total debt-to-net-worth ratio is seven percentage points higher in the United States, the total debt-to-income ratio for the United States exceeds Germany's ratio by almost 75\%. Thus, indebtedness is higher in the United States across all age groups (Table A2b) and all wealth and income classes (Tables A3b and A4b). In the United States, the lower quintiles of the income and wealth distribution in particular have much higher debt ratios. While in Germany, it is middle-aged households (in the 34 to 45 -year-old age range) that exhibit the highest debt ratios (typically due to the purchase of real estate), in the United States it is the young, who typically have high consumer credits and/or student loans. The willingness to go into debt is much more common in the United States, and access to credit markets (probably with fewer constraints) appears to be easier there than in Germany. 
Table 4. Overall portfolio composition

United States

Germany

(1) Composition of total gross wealth

\begin{tabular}{lcccc} 
& Mean (US\$) & Share (\%) & Mean (US\$) & Share (\%) \\
\hline Total gross wealth & 427,397 & 100.00 & 218,222 & 100.00 \\
& $(6,031)$ & $(0.00)$ & $(2,722)$ & $(0.00)$ \\
Owner-occupied property & 168,568 & 39.44 & 126,213 & 57.85 \\
& $(1,536)$ & $(0.42)$ & $(949)$ & $(0.63)$ \\
Other real estate & 56,768 & 13.28 & 35,531 & 16.28 \\
& $(1,592)$ & $(0.27)$ & $(875)$ & $(0.32)$ \\
Tangible assets & 3,730 & 0.87 & 2,183 & 1.00 \\
& $(186)$ & $(0.04)$ & $(72)$ & $(0.03)$ \\
Business assets & 80,625 & 18.86 & 16,705 & 7.65 \\
Financial assets and building & $(2,494)$ & $(0.46)$ & $(1,835)$ & $(0.76)$ \\
society savings agreements & 117,707 & 27.54 & 37,591 & 17.23 \\
\hline
\end{tabular}

(2) Composition of total household debt

\begin{tabular}{lcccc} 
& Mean (US\$) & Share (\%) & Mean (US\$) & Share (\%) \\
\hline Total household debt & 90,761 & 100.00 & 35,709 & 100.00 \\
Mortgage debts - owner occupied & $(896)$ & $(0.00)$ & $(619)$ & $(0.00)$ \\
property & 67,108 & 73.94 & 21,857 & 61.22 \\
Mortgage debts - other real estate & $(720)$ & $(0.36)$ & $(363)$ & $(1.00)$ \\
& 8,168 & 9.00 & 8,375 & 23.44 \\
Consumer debts & $(301)$ & $(0.29)$ & $(445)$ & $(1.00)$ \\
& 15,485 & 17.06 & 5,477 & 15.34 \\
& $(265)$ & $(0.28)$ & $(283)$ & $(0.70)$ \\
\hline
\end{tabular}

(3) Debt ratios (aggregate level)

\begin{tabular}{lcccc} 
& Ratio & (s.e.) & Ratio & (s.e.) \\
\hline Total debt/net worth & 0.27 & $(0.01)$ & 0.20 & $(0.00)$ \\
Total debt/household income & 12.94 & $(0.13)$ & 7.44 & $(0.12)$ \\
\hline
\end{tabular}

Note: The sample is top-trimmed at the 99.9 th percentile. All results are based on multiple imputations; bootstrap standard errors accounting for multiple imputation are shown in parentheses.

Source: Authors' calculations from the SCF 2013 and SOEP v30/v31.

Table 5 provides the distribution of wealth aggregates by net worth deciles (columns 1-4): net worth, occupational and private and social security pension wealth, as well as augmented wealth. Further, columns 5-7 provide the relative contributions of the respective wealth components to augmented wealth in the respective net worth decile.

Regarding net worth, the table confirms and sheds further light on the higher wealth concentration among households in the United States: Up to the eighth decile, net worth is slightly higher in Germany than in the United States. For the top decile, however, mean wealth is markedly higher in the United States: US\$2.6 million versus US\$1 million in Germany. 
Regarding social security pension wealth, the country comparison shows a similar pattern. Up to the ninth decile social security pension wealth is US\$30,000 to US\$60,000 higher in Germany than in the US, indicating the higher generosity of the pension scheme in Germany at least for the majority of the population. Only for the top decile does social security pension wealth in the US outperform the one in Germany.

The mean values for occupational and private pension wealth are rather similar in the two countries for the lower half of the net worth distribution. Beginning with the sixth net worth decile differences are starting to rise in favor of the United States. The difference is most pronounced in the top decile where it amounts to US\$380.000. Finally, with regard to augmented wealth, the pattern over the distribution is similar to the one of net worth. In the lower eight deciles German households possess more wealth than US households, while the opposite holds for the top two deciles. The absolute difference for the lower eight deciles vary between US\$10,000 for the eighth decile to US\$80,000 in the fourth decile. In the top decile the between-country difference amounts to roughly US\$2 million in favor of US households.

With regard to the relative contributions of net worth and pension wealth to augmented wealth along the deciles of net worth (column 5-7 in table 5), we find some quite similar patterns in both countries: For the bottom deciles, social security pension wealth makes up the largest relative portion of augmented wealth, but this portion declines over the net worth distribution. For example, in the United States (Germany) it falls from about $84 \%$ (90\%) in the second to $50 \%(58 \%)$ in the sixth to $8 \%(17 \%)$ in the tenth decile. At the same time, in both countries the portion of net worth increases over the deciles: from about $-8 \%(0 \%)$ in the second to $19 \%(22 \%)$ in the sixth to $74 \%(67 \%)$ in the tenth decile. The relative contributions of occupational and private pension wealth, however, show rather similar patterns for both countries. In the US, the share decreases from the first to the third decile. It then rises again up to the fifth decile and stays at this level up to the ninth decile. In Germany it starts with $26 \%$ in the first decile and also decreases to $10 \%$ in the second and third decile and then also rises again to around $20 \%$ and stays at this level up to the tenth decile. 
Table 5. Distribution of wealth by net worth deciles

\begin{tabular}{|c|c|c|c|c|c|c|c|}
\hline \multirow[t]{2}{*}{ Decile } & \multicolumn{4}{|c|}{ Mean (US\$) } & \multicolumn{3}{|c|}{ As share of augmented wealth (\%) } \\
\hline & Net worth & $\begin{array}{l}\text { Social } \\
\text { security } \\
\text { pension } \\
\text { wealth } \\
\end{array}$ & $\begin{array}{l}\text { Occupational } \\
\text { and private } \\
\text { pension } \\
\text { wealth }\end{array}$ & $\begin{array}{l}\text { Augmented } \\
\text { wealth }\end{array}$ & Net worth & $\begin{array}{l}\text { Social } \\
\text { security } \\
\text { pension } \\
\text { wealth }\end{array}$ & $\begin{array}{c}\text { Occupational } \\
\text { and private } \\
\text { pension } \\
\text { wealth } \\
\end{array}$ \\
\hline \multicolumn{8}{|c|}{ United States } \\
\hline 1 & $-60,954$ & 112,379 & 45,883 & 97,308 & -62.67 & 115.53 & 47.14 \\
\hline 2 & $-9,997$ & 100,096 & 28,520 & 118,619 & -8.43 & 84.39 & 24.04 \\
\hline 3 & -516 & 92,035 & 12,737 & 104,256 & -0.49 & 88.28 & 12.22 \\
\hline 4 & 3,035 & 98,472 & 22,186 & 123,692 & 2.45 & 79.64 & 17.91 \\
\hline 5 & 22,883 & 132,898 & 64,196 & 219,977 & 10.40 & 60.42 & 29.17 \\
\hline 6 & 60,104 & 158,896 & 96,468 & 315,468 & 19.05 & 50.37 & 30.57 \\
\hline 7 & 112,479 & 188,895 & 140,949 & 442,323 & 25.43 & 42.70 & 31.87 \\
\hline 8 & 201,757 & 210,075 & 183,052 & 594,884 & 33.92 & 35.31 & 30.77 \\
\hline 9 & 403,636 & 237,304 & 312,338 & 953,278 & 42.34 & 24.89 & 32.76 \\
\hline 10 & $2,636,165$ & 284,046 & 627,947 & $3,548,157$ & 74.30 & 8.01 & 17.70 \\
\hline Overall & 336,636 & 161,475 & 153,351 & 651,462 & 51.67 & 24.79 & 23.54 \\
\hline \multicolumn{8}{|c|}{ Germany } \\
\hline 1 & $-31,291$ & 147,661 & 40,163 & 156,533 & -20.04 & 94.38 & 25.65 \\
\hline 2 & -7 & 158,944 & 16,703 & 175,639 & 0.00 & 90.49 & 9.51 \\
\hline 3 & 615 & 131,391 & 14,884 & 146,891 & 0.42 & 89.46 & 10.12 \\
\hline 4 & 6,811 & 157,608 & 39,624 & 204,044 & 3.34 & 77.25 & 19.41 \\
\hline 5 & 28,402 & 193,367 & 56,957 & 278,726 & 10.19 & 69.39 & 20.42 \\
\hline 6 & 76,178 & 196,928 & 66,528 & 339,634 & 22.43 & 57.99 & 19.58 \\
\hline 7 & 143,243 & 219,349 & 112,603 & 475,195 & 30.15 & 46.16 & 23.69 \\
\hline 8 & 233,897 & 250,398 & 120,879 & 605,174 & 38.65 & 41.38 & 19.97 \\
\hline 9 & 365,569 & 274,895 & 182,926 & 823,390 & 44.40 & 33.39 & 22.21 \\
\hline 10 & $1,007,194$ & 254,042 & 250,733 & $1,511,968$ & 66.61 & 16.81 & 16.59 \\
\hline Overall & 182,513 & 200,407 & 90,122 & 473,043 & 38.58 & 42.37 & 19.05 \\
\hline
\end{tabular}

Note: The sample is top trimmed at the 99.9th percentile. All results are based on multiple imputations. Deciles refer to the distribution of net worth. Source: authors' calculations from the SCF 2013 and SOEP v30/v31.

\subsection{Wealth inequality in the United States versus Germany}

We measure wealth inequalities by means of two indices: the Gini index and the half-squared coefficient of variation (GE2). The GE2 belongs to the generalized entropy class of inequality indices, and is particularly sensitive to changes at the top of a distribution, whereas the Gini is more responsive to changes in the middle and bottom of the distribution. 
QQ plots in Figure 2 provide information on the correlation between different wealth aggregates and net worth. In both countries, the gap between augmented wealth (solid line) and net worth (grey line) continuously widens over the quantiles of net worth. This is primarily due to the increasing role of occupational and private pension wealth (dotted line), which plays a negligible role in the bottom quantiles. In contrast, the consideration of social security pension wealth (dashed line) is of utmost relevance for lower levels of net worth, and, thereafter increases only slightly. That is, starting at US\$100,000, the level of social security pension wealth remains approximately constant. As a result, social security pension wealth is higher than occupational and private pension wealth up to a level of net worth of about US\$300,000 in the United States, whereas this threshold is about US\$600,000 in Germany.

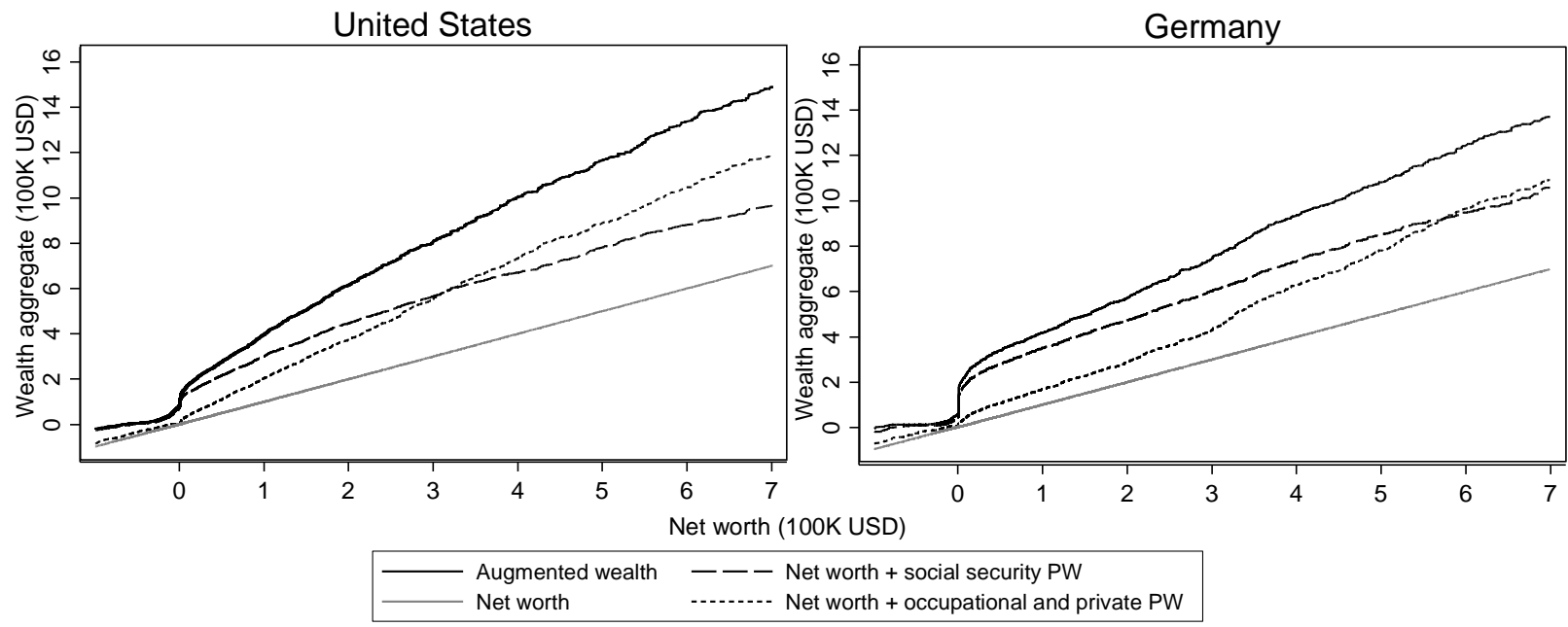

Note: Information for households with less than US\$100,000 and above US\$1 million of net worth are not presented. All results are based on multiple imputations. Source: authors' calculations from the SCF 2013 and SOEP v30/v31.

Figure 2. QQ plots for different wealth aggregates

Table 6 presents Gini coefficients for the different wealth aggregates in the two countries. Because indices are difficult to interpret if the distribution entails observations that hold negative wealth, we have additionally re-done the analysis for the total population with a bottom-coding of the wealth component at zero. Finally, to shed light on the inequalities among households that actually hold positive wealth, we have also derived all indices when excluding all households with zero or negative wealth. All results are detailed in Table 6 . We 
first comment on the results for the overall population. Pertaining to net worth, our results confirm the previous finding of markedly higher inequality in the United States. The Gini index (see for the GE2 table A1) is 0.892 as opposed to 0.765 in Germany. Adding social security pensions without survivor benefits to net worth reduces inequality. For example, the Gini index drops by about $20 \%$ (to 0.712 ) in the United States. In Germany, the reduction is even larger ( $31 \%$ to 0.525$)$ due to the greater importance of social security pension wealth. Adding social security pensions from survivor benefits further reduces inequality, but to a smaller extent. For the United States, for instance, the decrease is 0.008 Gini points.

When adding occupational and private pension wealth to net worth, the magnitude of the inequality-reducing effect is smaller compared to social security pension wealth. In both countries, the Gini index declines by about 7\%. From all five of the wealth aggregates considered here, inequality in augmented wealth is the smallest: the derived Gini index for US households shrinks by $21 \%$ to 0.701 . It is even greater in Germany, decreasing by $33 \%$ to 0.511 . Bottom-coding at zero has a quite minor effect on measured inequalities. Excluding households with zero or negative wealth yields markedly lower inequality indices. None of the two adjustments change the aforementioned general findings.

We complete the inequality analysis with a factor decomposition suited to studying the contribution of each wealth component to the inequality of augmented wealth. To keep the empirical analysis tractable and for more intuitive interpretation, we restrict our attention to the Gini index. Following Lerman and Yitzhaki (1985), the Gini index of country $k \in$ $\{U S$, Germany $\}$ can be decomposed as follows:

$$
\operatorname{Gini}_{k}=\sum_{f=1}^{F} r_{f, k} \times \operatorname{Gini}_{f, k} \times s_{f, k}=\sum_{f=1}^{F} C_{f, k} \times s_{f, k}=\sum_{f=1}^{F} O_{f, k}
$$

Here, Gini $_{k}$ denotes the Gini index of augmented wealth in a country; $r_{f, k}$ the Gini correlation between wealth component $w_{f, k}$ (with $f=1, \ldots, F$ ) and augmented wealth; $\operatorname{Gini}\left(w_{f, k}\right)=$ $\operatorname{Gini}_{f, k}$ the Gini index for wealth component $f$; and $s\left(w_{f, k}\right)=s_{f, k}$ the share of component $f$ in augmented wealth. The Gini correlation $r\left(w_{f, k}\right)=r_{f, k}$ measures the dependence between two random variables. Its properties are a mixture of Pearson's and Spearman's correlations. For 
any given marginal distribution, the range of the Gini correlation is $[-1,1]$ (see Schröder et al., 2014). The concentration coefficient of a wealth component, $C\left(w_{f, k}\right)=C_{f, k},\left(=r_{f, k} \times \operatorname{Gini}_{f, k}\right)$, builds on the distribution sorted by augmented wealth. ${ }^{37} \mathrm{~A}$ smaller concentration coefficient of a given wealth component compared to the concentration coefficient of augmented wealth indicates that this wealth component is more prominent in the lower part of the distribution and vice versa. The product $O_{f, k}=r_{f, k} \times \operatorname{Gini}_{f, k} \times s_{f, k}$ can be interpreted as the overall absolute contribution of a particular wealth aggregate to overall inequality in augmented wealth, while $o_{f, k}=\frac{o_{f, k}}{\text { Gini }_{k}}$ gives the relative contribution.

${ }^{37}$ The concentration coefficient for augmented wealth is identical to its Gini coefficient. 
Table 6. Gini-coefficient by wealth aggregate

\begin{tabular}{|c|c|c|c|c|c|c|}
\hline Wealth aggregate & \multicolumn{2}{|c|}{ Total population } & \multicolumn{2}{|c|}{$\begin{array}{c}\text { Total population, bottom } \\
\text { coding at } 0\end{array}$} & \multicolumn{2}{|c|}{$\begin{array}{l}\text { Population with positive } \\
\text { wealth component }\end{array}$} \\
\hline \multicolumn{7}{|c|}{ United States } \\
\hline Net worth & 0.892 & $(0.031)$ & 0.855 & $(0.029)$ & 0.801 & $(0.032)$ \\
\hline $\begin{array}{l}\text { Net worth + own } \\
\text { social security pension } \\
\text { wealth }\end{array}$ & 0.712 & $(0.036)$ & 0.693 & $(0.036)$ & 0.690 & $(0.037)$ \\
\hline $\begin{array}{l}\text { Net worth + social } \\
\text { security pension } \\
\text { wealth }\end{array}$ & 0.704 & $(0.036)$ & 0.750 & $(0.035)$ & 0.683 & $(0.037)$ \\
\hline $\begin{array}{l}\text { Net worth }+ \\
\text { occupational and } \\
\text { private pension } \\
\text { wealth }\end{array}$ & 0.828 & $(0.031)$ & 0.807 & $(0.031)$ & 0.761 & $(0.034)$ \\
\hline Augmented wealth & 0.701 & $(0.035)$ & 0.688 & $(0.035)$ & 0.684 & $(0.035)$ \\
\hline \multicolumn{7}{|c|}{ Germany } \\
\hline Net worth & 0.765 & $(0.045)$ & 0.735 & $(0.039)$ & 0.630 & $(0.045)$ \\
\hline $\begin{array}{l}\text { Net worth + own } \\
\text { social security pension } \\
\text { wealth }\end{array}$ & 0.525 & $(0.042)$ & 0.516 & $(0.040)$ & 0.508 & $(0.040)$ \\
\hline $\begin{array}{l}\text { Net worth + social } \\
\text { security pension } \\
\text { wealth }\end{array}$ & 0.512 & $(0.041)$ & 0.564 & $(0.042)$ & 0.495 & $(0.040)$ \\
\hline $\begin{array}{l}\text { Net worth + } \\
\text { occupational and } \\
\text { private pension } \\
\text { wealth }\end{array}$ & 0.712 & $(0.040)$ & 0.696 & $(0.036)$ & 0.627 & (0.039) \\
\hline Augmented wealth & 0.511 & (0.038) & 0.505 & (0.036) & 0.500 & (0.036) \\
\hline
\end{tabular}

We also compute how the Gini coefficient of augmented wealth changes $\left(\Delta G_{k}\right)$ due to an equiproportional marginal $1 \%$ increase of a particular wealth component, holding all other wealth components constant.

Table 7 summarizes the results from the factor composition. As pointed out above, net worth is the key driver of augmented wealth inequality. Its relative contribution $\left(o_{f}\right)$ is about $63 \%$ in the United States and 52\% in Germany. In the United States, the second most important driver is occupational and private pensions at almost $25 \%$, followed by social security pensions without survivor benefits at $11 \%$. In Germany, social security pensions without survivor benefits and 
occupational and private pensions are of similar magnitude with relative contributions of $22 \%$ and $23 \%$, respectively. In both countries, social security pensions from survivor benefits make only a small relative contribution of $1 \%$ in the United States and 3\% in Germany.

The wealth-component-specific inequalities have already been addressed in Table 6. Of interest, however, are the Gini correlations. The correlation is highest for net worth - exceeding 0.9 in both countries - indicating a rather strong statistical dependence between net worth and augmented wealth. Gini correlations for social security pension wealth without survivor benefits are lower, at 0.784 in the United States and 0.646 in Germany. Correlations for occupational and private pension wealth differ in a similar fashion: The correlation is 0.901 in the United States and 0.778 in Germany, suggesting that the statistical association between occupational and private pensions and augmented wealth is lower in Germany. A potential explanation for the lower correlation in Germany might be Riester pensions, a subsidized voluntary private saving scheme for retirement that is designed to facilitate savings for lowincome parents, who usually do not hold significant net worth (see Corneo et al. 2015). There is also evidence that the Riester scheme crowds out savings in non-subsidized savings schemes (see Corneo et al., 2009 and 2010). Other potential explanations are differences between wealthy and non-wealthy households in risk and time preferences, financial literacy, or access to financial products. The lowest Gini correlation can be found for social security pensions from survivor benefits, whose value is 0.573 in the United States and 0.365 in Germany. In neither country is the Gini correlation negative. Hence, none of the three wealth components is negatively associated with augmented wealth. ${ }^{38}$ Finally, the concentration coefficient for net worth and occupational and private pension wealth is higher than that for augmented wealth in both countries, i.e., both wealth components are more relevant in the upper part of the augmented wealth distribution.

\footnotetext{
${ }^{38}$ The general results from a factor composition of GE2 are roughly the same and the results are detailed in Table A2 in the Appendix.
} 
Table 7. Inequality decomposition using the Gini-coefficient

\begin{tabular}{|c|c|c|c|c|c|c|c|}
\hline \multirow[b]{2}{*}{ Wealth aggregate } & \multicolumn{4}{|c|}{ Components } & \multicolumn{3}{|c|}{ Contribution } \\
\hline & $r_{f, k}$ & $s_{f, k}$ & $\operatorname{Gini}_{f, k}$ & $C_{f, k}$ & $\begin{array}{c}O_{f, k} \\
\text { (absolute) }\end{array}$ & $\begin{array}{c}o_{f, k} \\
\text { (relative, \%) }\end{array}$ & $\Delta G_{k}$ \\
\hline \multicolumn{8}{|c|}{ United States } \\
\hline Net worth & $\begin{array}{c}0.960 \\
(0.039)\end{array}$ & $\begin{array}{c}0.517 \\
(0.009)\end{array}$ & $\begin{array}{c}0.892 \\
(0.165)\end{array}$ & $\begin{array}{c}0.856 \\
(0.159)\end{array}$ & $\begin{array}{c}0.442 \\
(0.083)\end{array}$ & $\begin{array}{l}63.12 \\
(1.25)\end{array}$ & $\begin{array}{c}0.114 \\
(0.008)\end{array}$ \\
\hline $\begin{array}{l}\text { Social security pension } \\
\text { wealth without } \\
\text { survivor benefit }\end{array}$ & $\begin{array}{c}0.784 \\
(0.020)\end{array}$ & $\begin{array}{l}0.229 \\
(0.005)\end{array}$ & $\begin{array}{l}0.440 \\
(0.081)\end{array}$ & $\begin{array}{l}0.345 \\
(0.064)\end{array}$ & $\begin{array}{l}0.079 \\
(0.015)\end{array}$ & $\begin{array}{l}11.27 \\
(0.52)\end{array}$ & $\begin{array}{l}-0.116 \\
(0.003)\end{array}$ \\
\hline $\begin{array}{l}\text { Social security pension } \\
\text { wealth from survivor } \\
\text { benefit }\end{array}$ & $\begin{array}{c}0.573 \\
(0.023)\end{array}$ & $\begin{array}{c}0.019 \\
(0.000)\end{array}$ & $\begin{array}{c}0.691 \\
(0.127)\end{array}$ & $\begin{array}{c}0.396 \\
(0.074)\end{array}$ & $\begin{array}{c}0.007 \\
(0.001)\end{array}$ & $\begin{array}{l}1.06 \\
(0.05)\end{array}$ & $\begin{array}{l}-0.008 \\
(0.000)\end{array}$ \\
\hline $\begin{array}{l}\text { Occupational and } \\
\text { private pension wealth }\end{array}$ & $\begin{array}{c}0.901 \\
(0.039)\end{array}$ & $\begin{array}{c}0.235 \\
(0.006)\end{array}$ & $\begin{array}{c}0.811 \\
(0.151)\end{array}$ & $\begin{array}{c}0.731 \\
(0.138)\end{array}$ & $\begin{array}{c}0.172 \\
(0.033)\end{array}$ & $\begin{array}{l}24.55 \\
(0.98)\end{array}$ & $\begin{array}{c}0.010 \\
(0.007)\end{array}$ \\
\hline $\begin{array}{l}\text { Total inequality } \\
\text { (augmented wealth) }\end{array}$ & & & 0.701 & 0.701 & 0.701 & 100.00 & 0.00 \\
\hline \multicolumn{8}{|c|}{ Germany } \\
\hline Net worth & $\begin{array}{c}0.900 \\
(0.034)\end{array}$ & $\begin{array}{c}0.386 \\
(0.008)\end{array}$ & $\begin{array}{c}0.765 \\
(0.122)\end{array}$ & $\begin{array}{c}0.688 \\
(0.112)\end{array}$ & $\begin{array}{c}0.265 \\
(0.044)\end{array}$ & $\begin{array}{l}51.93 \\
(1.52)\end{array}$ & $\begin{array}{c}0.133 \\
(0.010)\end{array}$ \\
\hline $\begin{array}{l}\text { Social security pension } \\
\text { wealth without } \\
\text { survivor benefit }\end{array}$ & $\begin{array}{c}0.646 \\
(0.016)\end{array}$ & $\begin{array}{c}0.377 \\
(0.006)\end{array}$ & $\begin{array}{l}0.466 \\
(0.070)\end{array}$ & $\begin{array}{c}0.301 \\
(0.045)\end{array}$ & $\begin{array}{c}0.114 \\
(0.017)\end{array}$ & $\begin{array}{l}22.22 \\
(0.90)\end{array}$ & $\begin{array}{l}-0.155 \\
(0.007)\end{array}$ \\
\hline $\begin{array}{l}\text { Social security pension } \\
\text { wealth from survivor } \\
\text { benefit }\end{array}$ & $\begin{array}{c}0.365 \\
(0.024)\end{array}$ & $\begin{array}{c}0.046 \\
(0.001)\end{array}$ & $\begin{array}{l}0.836 \\
(0.128)\end{array}$ & $\begin{array}{c}0.305 \\
(0.048)\end{array}$ & $(0.002)$ & $(0.20)$ & $\begin{array}{l}-0.019 \\
(0.002)\end{array}$ \\
\hline $\begin{array}{l}\text { Occupational and } \\
\text { private pension wealth }\end{array}$ & $\begin{array}{c}0.778 \\
(0.028)\end{array}$ & $\begin{array}{c}0.191 \\
(0.005)\end{array}$ & $\begin{array}{c}0.797 \\
(0.128)\end{array}$ & $\begin{array}{c}0.620 \\
(0.099)\end{array}$ & $\begin{array}{c}0.118 \\
(0.019)\end{array}$ & $\begin{array}{l}23.09 \\
(1.11)\end{array}$ & $\begin{array}{c}0.040 \\
(0.008)\end{array}$ \\
\hline $\begin{array}{l}\text { Total inequality } \\
\text { (augmented wealth) }\end{array}$ & & & 0.511 & 0.511 & 0.511 & 100.00 & 0.00 \\
\hline
\end{tabular}

Note: The sample is top-trimmed at the 99.9 percentile. All results are based on multiple imputations; bootstrap standard errors accounting for multiple imputation are shown in parentheses.

Source: authors' calculations from the SCF 2013 and SOEP v30/v31.

The last column of table 7 shows how the Gini coefficient of augmented wealth changes due to an equi-proportional marginal $1 \%$ increase of a wealth component (all other components held constant). We find similar patterns in the two countries. While a marginal increase in net worth leads to a surge in augmented wealth inequality $(0.114$ Gini points in the United States vs. 0.133 in Germany), the opposite is true for social security pension wealth. A marginal change in occupational and private pension wealth, however, has only a minor inequality-enhancing 
effect on augmented wealth. The magnitude for social security pension wealth from survivor benefits is also small, although survivor benefits tend to decrease inequality.

The results from the decomposition can be used to derive counterfactual distributions by swapping coefficients between countries. We study two counterfactuals:

1. The first counterfactual seeks to investigate how between-country differences in wealth shares alter overall inequality (share effect). The share effect is estimated by replacing the wealth shares in country $k$ with the shares from country $k^{\prime}$ is $\operatorname{Share}_{k}=\sum_{f=1}^{F} C_{f, k} \times$ $s_{f, k^{\prime}}-\sum_{f=1}^{F} C_{f, k} \times s_{f, k}$.

2. The second counterfactual seeks to investigate how the difference in two countries' concentration coefficients for a particular wealth component alters overall inequality (concentration effect). For component $w_{f, k}$, the effect is: Concentration , $_{, k}=$ $\left(C_{f, k^{\prime}}-C_{f, k}\right) \times s_{f, k}$. The total concentration effect is the sum of all wealth components' concentration coefficient: $\sum_{f=1}^{F}$ Concentration $_{f, k}$

Table 8 summarizes the share and concentration effects. In the case of the United States, the share effect is negative: If the wealth shares in the United States were the same as in Germany, this would lead to a 0.087 (about $11.8 \%$ ) reduction of the Gini coefficient in the augmented wealth distribution in the United States. In Germany, the share effect has the inverse sign and is smaller in absolute terms (12.6\% increase). The country-specific total concentration effects over all wealth aggregates, in absolute terms, are larger than the share effects, meaning that the inequality gap between the United States and Germany, as measured by the Gini difference, is mainly driven by cross-country differences in wealth-aggregate-specific inequalities. The overall concentration effect results from differences in inequalities of net worth in both countries (0.087 in the US versus 0.065 in Germany). Besides this, the concentration effect for each wealth aggregate is, in all cases, rather small and negative (positive) for the US (Germany). 
Table 8. Share and concentration effects from counterfactuals

\begin{tabular}{lcc} 
& United States & Germany \\
\hline Share effect & -0.083 & 0.065 \\
\hline Total concentration effect & -0.125 & 0.107 \\
\hline Concentration effects by wealth aggregate & & \\
\hline Net worth & -0.087 & 0.065 \\
$\begin{array}{l}\text { Social security pension wealth without } \\
\text { survivor benefits }\end{array}$ & -0.010 & 0.017 \\
$\begin{array}{l}\text { Social security pension wealth from survivor } \\
\text { benefit }\end{array}$ & -0.002 & 0.004 \\
\begin{tabular}{l} 
Occupational and private pension wealth \\
\hline
\end{tabular} & -0.026 & 0.021 \\
\hline
\end{tabular}

Note: Effects computed from point estimates in Table 7.

\subsection{Age-wealth profiles}

According to the life-cycle hypothesis, wealth increases up to retirement age and decreases smoothly thereafter, implying a hump-shaped age-wealth profile (Ando and Modigliani, 1963). With simple cross-sectional data at hand, we are not able to distinguish among age, period, and cohort effects. Thus, we provide estimates of wealth profiles using variation over age in the 2013 cross-section.

For both countries, we estimate age-wealth profiles on the basis of age of the household head. The age-wealth profiles are presented for four wealth aggregates - namely, net worth, social security and occupational and private pensions, and augmented wealth (see Figure 3). Predictions of wealth-age profiles rely on OLS regressions for multiple imputed data, the specification is:

$$
w_{f, h, k}=\alpha_{k}+\beta_{k} \times a g e_{h, k}+\gamma_{k} \times\left(a g e_{h, k}\right)^{2}+\delta_{k} \times\left(a g e_{h, k}\right)^{3}+\varepsilon_{h, k}
$$

with $w_{f, h, k}$ denoting wealth aggregate owned by household $h$ of wealth aggregate $f$ in country $k, a g e_{h, k}$ the age of the household head in years, and $\varepsilon_{h, k}$ the error term. Age is considered with a quadratic term, which considers the typical dissaving effect after retirement, while the polynomial of the third order is used for robustness purposes. 
For the graphical presentation in Figure 3, we normalized the estimated wealth profiles in each country by the respective mean value at the age of 45 to ease the comparisons by controlling for the substantial difference in wealth levels in Germany and the United States. ${ }^{39}$

The general message from Figure 3 is that all estimated age-wealth profiles support the lifecycle hypothesis, exhibiting the expected hump-shaped profile. It is also interesting to note that for both countries, the shapes of net worth profiles and augmented wealth are very similar up to the age of 60 . For higher ages, in Germany there is a somewhat stronger dissaving effect than in the United States, also starting at earlier ages. One potential explanation for the lower dissaving rate among elderly Americans compared to Germans is the greater need of the former to put aside precautionary savings to pay for future medical expenses in old age. In Germany, the majority of medical expenses are covered by the national health plan or nursing home and elderly care insurance. In the United States, in contrast, elderly Americans are subject to considerably greater out-of-pocket medical expenses. Moreover, elderly care insurance is much more limited in the United States, with regard to both the dollar level of coverage and the term of coverage (the typical policy covers the insured for a maximum of five years). As a result, older American must continue to save (or, at least, not dis-save as much) to provide for this possible contingency. ${ }^{40}$ Besides medical expenses, savings in the United States might also represent reserves to finance education for dependents. Additionally, owners of property wealth can profit from a rise in values. Given that the share of property owners is higher in the United States compared to Germany, this may also explain why older Americans still show increases in net worth.

For social security pension wealth, we find a steeper profile in Germany than in the United States before retirement. One possible explanation is the tighter relationship between earnings and pension entitlements in Germany, the principle of equivalence. This principle implies that the age profile for social security pension wealth closely tracks the earnings profile. In the

\footnotetext{
${ }^{39}$ Additionally, Figure A3 in the Appendix provides age-wealth profiles for three aggregates: (a) net worth plus public pensions without survivor benefits; (b) net worth plus public pensions from survivor benefits; (c) net worth plus private pensions; (d) total pension wealth.

${ }^{40}$ Some corroboration is provided in a recent study by Banks et al. (2016) investigating consumption patterns at older ages in the United States and the United Kingdom. They find that the greater need for precautionary savings for future medical expenses in the United States almost fully explains the steeper decline in non-durable consumption in the United Kingdom compared to the United States in old age.
} 
United States, replacement rates decrease in earnings, meaning that age profiles for earnings and social security pension wealth are less strongly linked.

For occupational and private pension wealth, the age profile is markedly steeper in the United States compared to Germany. In the United States, mean wealth increases by a factor of 3.6 between 45 and 65, while in Germany, the respective pension wealth at 65 is 2.6 times that at 45. For higher ages, the gap between the profiles declines.

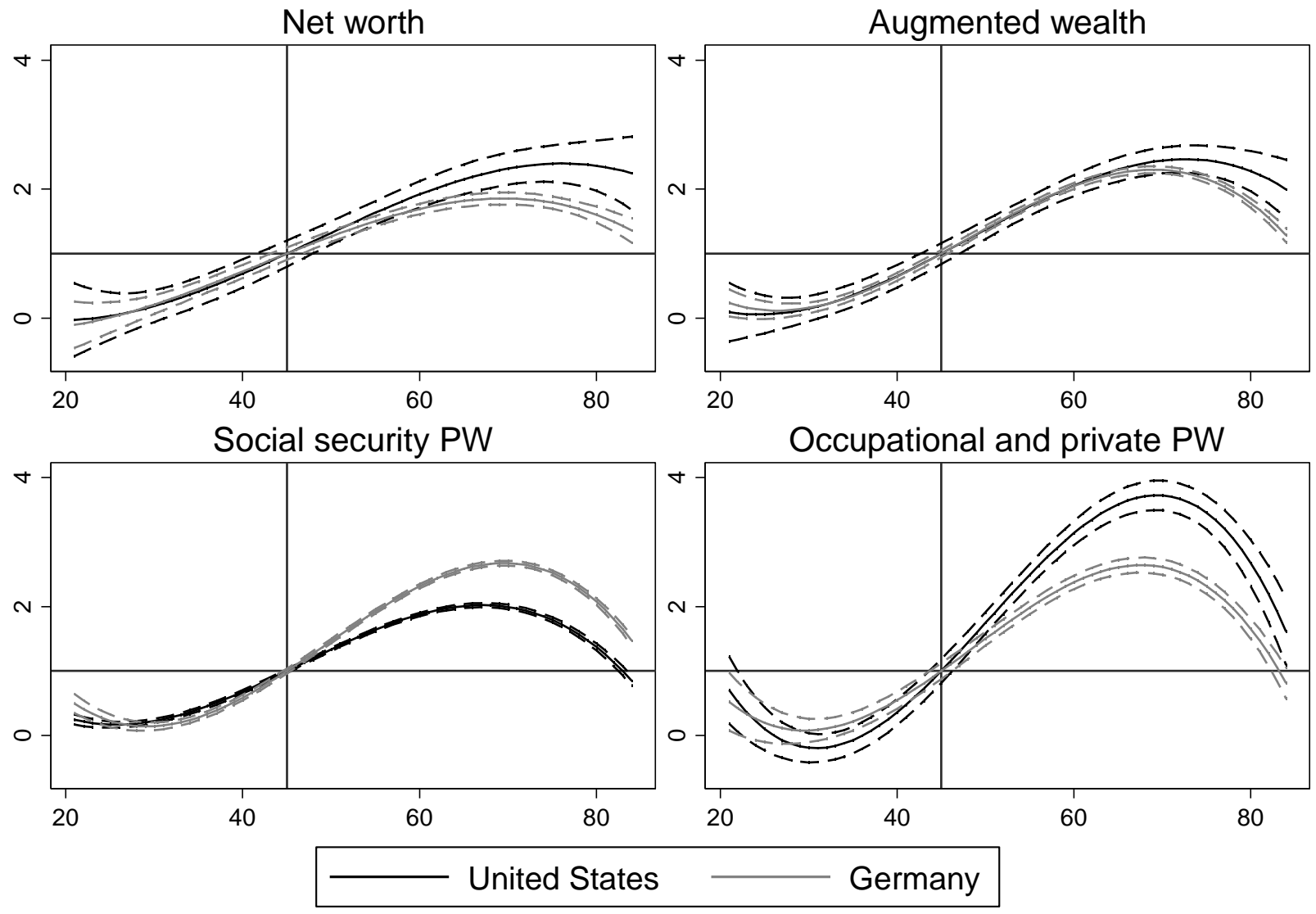

Note: The sample is top trimmed at the 99.9th percentile. All results are based on multiple imputations. Dashed lines represent 95\% confidence bands. Source: authors' calculations from the SCF 2013 and SOEP v30/v31.

Figure 3. Normalized age-wealth profiles

\section{Conclusion}

We find that in 2013 average net worth in the United States is US\$337,000, about twice as high as in Germany, while up to the eighth decile net worth is higher in Germany than in the United 
States. We also find that pension wealth makes up a sizeable portion of household wealth $48 \%$ on average of augmented wealth in the United States and 61\% in Germany. Average social security pension wealth in dollar terms is higher in Germany than the United States US\$200,000 versus US\$161,000 - but the reverse is true for occupational and private pension wealth - US\$90,000 versus US\$153,000. Average total pension wealth is therefore higher in the United States - US\$315,000 versus US\$291,000. Including pension wealth also alters the relative positions in average and median wealth in the two countries. At US\$651,000, average augmented wealth in the United States is 1.4 times higher than in Germany but the median is higher in Germany: US\$327,000 versus US\$247,000, which underlines the relative importance of pension wealth in Germany.

In both countries, the incorporation of pension wealth in the household portfolio positions reduces measured wealth inequalities, but wealth inequality is reduced more in Germany through the addition of pension wealth than in the United States. With regard to net worth, our results confirm the previous finding of markedly higher inequalities in the United States. The Gini index is 0.892 in contrast to 0.765 in Germany. Adding social security pension wealth to net worth reduces inequality. The Gini index drops by $21 \%$ (to 0.704 ) in the United States, while in Germany, the reduction is even greater ( $33 \%$ to 0.512 ) due to the higher importance of social security pension wealth. Adding occupational and private pension wealth to net worth also reduces inequality, but the magnitude of the effect is smaller. In both countries, the Gini index declines by about seven percent. Adding social security and occupational and private pension wealth to net worth, we obtain augmented wealth. The respective Gini index in United States shrinks by 0.191 points, from 0.892 to 0.701 , and by 0.254 points (33\% reduction) in Germany to 0.511 . The redistributive impact of pension wealth is therefore greater in Germany. The primary effect is from social security pension wealth, which reflects the higher magnitude of social security pension wealth in Germany in both dollar and relative terms.

Putting the results in a broader perspective, we would have expected the wider social safety net in Germany relative to the United States would imply that middle-class and poor Germans need to save less for job loss, sickness, and old age than corresponding Americans. 
We would expect this primarily because of the higher social security pensions in Germany than in the United States. Also, university education is free in Germany, which means that unlike Americans, Germans have no need to save for university tuition. In general, one would think that a wider social safety net would mean less need for precautionary savings. However, net worth is actually higher in Germany than in the United States up to the eighth decile. Future research about net worth and augmented wealth in the two countries should therefore seek to explain this rather surprising finding and should investigate how differences in institutional settings such as the social safety net, incentives for wealth accumulation, and potential cultural differences play a role.

Finally, our research has shown that a cross-country comparison of wealth is sensitive to the choice of the wealth aggregate. Augmented wealth may give a more accurate picture of the welfare positions of households in different countries then net worth. Nevertheless, interpretations should be made with caution because of the restricted convertibility of social security pension wealth. ${ }^{41}$

\footnotetext{
${ }^{41}$ The OECD guidelines for Micro Statistics on Household Wealth (OECD 2013: 71) state that "The exclusion of entitlements in social security schemes, as recommended here for micro statistics on household wealth, is primarily for practical reasons and to maintain consistency with the SNA's definition of financial assets. It reflects the view that reliable estimates of pension entitlements in social security schemes may not be readily available in many countries, especially for individual households, and that the case for departing from the SNA on this issue is not strong at this time." However, data providers may modify their questionnaires or find other ways to estimate public pension wealth to provide a more precise picture of wealth levels and wealth inequality across countries.
} 


\section{References}

Acemoglu, D., Robinson, J.A. (2012): Why Nations Fail - The Origins of Power, Prosperity, and Poverty, New York: Crown Publisher.

Almås, I., Mogstad, M. (2012): Older or Wealthier? The Impact of Age Adjustment on Wealth Inequality, Scandinavian Journal of Economics, 114, 24-54.

Ando, A., and Modigliani, F. (1963): The "Life Cycle" Hypothesis of Saving: Aggregate Implications and Tests, The American Economic Review, 53(1), 55-84.

Arbeitsgemeinschaft berufsständischer Versorgungseinrichtungen e.V. (ABV) (2016): Daten und Fakten. http://www.abv.de/verlaessliche-struktur.html.

Attanasio, O., Brugiavini, A. (2003): Social security and households' saving, Quarterly Journal of economics, 118, 1075-1119.

Attanasio, O., and Hoynes, H. (2000): Differential Mortality and Wealth Accumulation, The Journal of Human Resources, 35 (1), 1-29.

Azpitarte, F. (2011): Measurement and identification of asset-poor households: a cross-national comparison of Spain and the United Kingdom. The Journal of Economic Inequality, 9, 87-110.

Azpitarte, F. (2012): Measuring Poverty Using Both Income and Wealth: A Cross-Country Comparison Between the U.S. and Spain, Review of Income and Wealth, 58, 24-50.

Bosworth, B., Burtless, G. (2004): Pension Reform and Saving, National Tax Journal, 57, 703-727.

Bover, O. (2010): Wealth inequality and household structure: US vs. Spain, The Review of Income and Wealth, 56, 259-290.

Bover, O., Casado, J.M., Costa, S., Du Caju, P., McCarthy, Y., Sierminska, E., Tzamourani, P., Villanueva, E., Zavadil, T. (2016): The Distribution of Debt across Euro-Area Countries: The Role of Individual Characteristics, Institutions, and Credit Conditions, International Journal of Central Banking, International Journal of Central Banking, 12, 71-128.

Boyle, P., Murray, J. (1979): Social Security Wealth and Private Saving in Canada, The Canadian Journal of Economics, 12, 456-468.

Browning, M., Lusardi, A. (1996): Household Saving: Micro Theories and Micro Facts, Journal of Economic Literature, 34, 1797-1855.

Bundesministerium für Arbeit und Soziales (BMAS) (2012a): Ergänzender Bericht der Bundesregierung zum Rentenversicherungsbericht 2012 gemäß $\S 154$ Abs. 2 SGB VI (Alterssicherungsbericht 2012).

Banks, J., Blundell, R., Levell, P., Smith, J. (2016): Life-Cycle Consumption Patterns at Older Ages in the US and the UK: Can Medical Expenditures Explain the Difference? NBER Working Paper No. 22513, August.

Bundesministerium für Arbeit und Soziales (BMAS) (2012b): Verbreitung der Altersversorge 2011. Endbericht, Federal Ministry of Labour and Social Affairs. 
Bönke, T., Grabka, M.M., Schröder, C., Wolff, E.N., and Zyska, L. (2016): The joint distribution of net worth and pension wealth in Germany, SOEPpapers on Multidisciplinary Panel Data Research, 853.

Cagetti, M. (2003): Wealth Accumulation Over the Life Cycle and Precautionary Savings, Journal of Business and Economic Statistics, 21, 339-353.

Chetty, R., Stepner, M., Abraham, S., Lin, S., Scuderi, B., Turner, N. Bergeron, A. and Cutler, D. (2016): The Association Between Income and Life Expectancy in the United States, 200114, Journal of the American Medical Association 315(16): 1750-1766.

Corneo, G., Keese, M., and Schröder, C. (2009): The Riester Scheme and Private Savings: An Empirical Analysis based on the German SOEP, Schmollers Jahrbuch: Journal of Applied Social Science Studies, 129(2), 321-332.

Corneo, G., Schröder, C., and König, J. (2015): Distributional effects of subsidizing retirement savings accounts: Evidence from Germany," Discussion Papers, 2015/18.

Corneo, G., Keese, M., and Schröder, C (2010): The Effect of Saving Subsidies on Household Saving - Evidence from Germanys, Ruhr Economic Papers, 170.

Cowell, F., Karagiannaki, E., McKnight, A. (2012), Mapping and Measuring the Distribution of Household Wealth: A Cross-Country Analysis, CASE working paper 165.

Cowell, F., Nolan, B., Olivera, J., and VanKerm, P. (2016): Wealth, Top Incomes and Inequality, in Wealth: Economics and Policy, Hamilton, K., and Hepburn, C., Editors, Forthcoming, Oxford University Press.

Davies, J.B., Sandström, S., Shorrocks, A. Wolff, E.N. (2011): The Level and Distribution of Global Household Wealth, Economic Journal, 121, 223-254.

Delavande, A., and Rohwedder, S. (2011): Differential Survival in Europe and the United States: Estimates Based on Subjective Probabilities of Survival, Demography, 48(4), 1377-1400.

Deutsche Rentenversicherung Bund (DRV-Bund) (2015): Rentenversicherung in Zahlen 2015.

Dicks-Mireaux, L., King, M. (1984): Pension Wealth and Household Savings: Tests of Robustness, Journal of Public Economics, 23, 115-139.

Eurosystem (2013): The Eurosystem Household Finance and Consumption Survey Results from the first wave, Statistics Paper Series, 2.

Eurosystem (2009), Housing Finance in the Euro Area, Occasional Paper Series, 101.

Federal Statistical Office (2015a): Finanzen und Steuern. Personal des öffentlichen Dienstes, Fachserie 14, Reihe 6, Wiesbaden.

Frick, J.R., Headey, B. (2009): Living Standards in Retirement: Accepted International Comparisons are Misleading, Schmollers Jahrbuch: Journal of Applied Social Science Studies/Zeitschrift für Wirtschafts-und Sozialwissenschaften, 129, 309-319.

Frick, J.R., and Grabka, M.M. (2010): Old-age Pension Entitlements Mitigate Inequality-but Concentration of Wealth Remains High, DIW Berlin Weekly Report, 8, 55-64. 
Frick, J.R., and Grabka, M.M. (2013): Public Pension Entitlements and the Distribution of Wealth, in: Janet C. Gornick and Markus Jäntti (eds.): "Income Inequality: Economic Disparities and the Middle Class in Affluent Countries," Stanford University Press, 362388.

Gale, W.G. (1998): The Effects of Pensions on Household Wealth: A Reevaluation of Theory and Evidence, Journal of Political Economy, Vol. 106, 706-723.

Gornick, J.C., Munzi, T., Sierminska, E., Smeeding, T.M. (2009) Income, Assets, and Poverty: Older Women in Comparative Perspective, Journal of Women, Politics and Policy, 30, 272-300.

Grabka, M.M., Westermeier, C. (2015): Editing and Multiple Imputation of Item Non-response in the Wealth Module of the German Socio-Economic Panel. SOEP Survey Papers Series C - Data Documentation, 272.

Gullason, E.T., Kolluri, B.R., Panik, M.J. (1993): Social Security and Household Wealth Accumulation: Refined Microeconometric Evidence, The Review of Economics and Statistics, 75, 548-551.

Gustman,A.L., Mitchell,O.S., Samwick, A.A., Steinmeier, T.L. (1997): Pension and Social Security Wealth in the Health and Retirement Study, NBER Working Paper Series, 5912.

Jianakoplos, N.A., Menchik, P.L. (1997): Wealth Mobility, The Review of Economic and Statistics, 79(1), 18-31.

Kaas, L., Kocharkov, G., and Preugschat, E. (2015): Wealth Inequality and Homeownership in Europe, CESifo Working Paper No. 5498, September.

Kitagawa, E.M., Hauser, Ph.M. (2014): Differential Mortality in the United States. A Study in Socioeconomic Epidemiology. Harvard University Press.

Kennickell, A.B. (2008): Survey of Consumer Finances. The Role of Over-Sampling of the Wealthy in the Survey of Consumer Finances. https://www.federalreserve.gov/econresdata/scf/files/index kennickell.html.

Leimer, D.R., Lesnoy, S.D. (1982): Social Security and Private Saving: New Time-series Evidence, Journal of Political Economy, 90, 606-629.

Maunu, T. (2010): The distribution of pension wealth in Finland, Finnish Centre for Pensions Working Papers, 3.

Mazzaferro, C., Toso, S. (2005): The Effects of Social Security on the Distribution of Wealth in Italy, Child - Centre for Household, Income, Labour and Demographic Economics Working Paper, 11.

Moffitt, R.A. (1984): Trends in Social Security Wealth by Cohort, in: NBER books, Economic Transfers in the United States, Chapter 6, 327-358.

Müller, P. (2016): Poverty in Europe: Sociodemographics, Portfolios and Consumption of Wealth Poor Households, LWS working papers series, 22. 
OECD (2008): Pension Country Profile: United States. (Extract from the OECD Private Pensions Outlook 2008), p. 297-303.

OECD (2013): OECD Guidelines for Micro Statistics on Household Wealth, OECD Publishing. http://dx.doi.org/10.1787/9789264194878-en

Ostry, J.D., Berg, A., Tsangarides, C.G. (2012): Redistribution, Inequality, and Growth, IMF Staff Discussion Note, SDN/14/02.

Paradowski, P. Flynn, L. (2015): Wealth Distribution and Individual Voting Preferences: A Comparative Perspective, LWS working papers series, 19.

Roine, J., Waldenström, D. (2009): Wealth Concentration over the Path of Development: Sweden, 1873-2006. The Scandinavian Journal of Economics, 111(1), 151-187.

Samwick, A.A. (2000): Is Pension Reform Conducive to Higher Saving? Review of Economics and Statistics, 82, 264-272.

Schröder, C., Golan, J., and Yitzhaki, S. (2014): Inequality and the time structure of earnings: evidence from Germany, Journal of Economic Inequality, 12(3), 393-409.

Sierminska, E., A. Brandolini, and T. Smeeding (2006): The Luxembourg Wealth Study, A crosscountry comparable database for household wealth research, Journal of Economic Inequality, 4, 375-383.

Sierminska, E., Takhtamanova, Y. (2006): Wealth Effects Out of Financial and Housing Wealth: Cross Country and Age Group Comparisons, LWS working papers series, 4.

Sierminska, E., Bicáková, A. (2007): Homeownership Inequality and the Access to Credit Markets. Can Credit Availability Explain Cross-country Differences in the Inequality of Homeownership across Income of Young Households?, LWS working papers series, 5.

Shamsuddin, A.F.M. (2001): Public Pension and Wealth Inequality in Canada, Applied Economics Letters, 8, 315-320.

Stiglitz, J.E. (2012): The Price of Inequality - How Today's Divided Society Endangers Our Future, New York: Norton.

Von Gaudecker, H.M., Scholz, R.D. (2007): Differential mortality by lifetime earnings in Germany. Demographic research, 17(4), 83-108.

Wagner, G.G., Frick, J.R., and Schupp, J. (2007): The German Socio-Economic Panel Study (SOEP) - Scope, Evolution and Enhancements, Schmollers Jahrbuch (Journal of Applied Social Science Studies), 127(1), 139-169.

Westermeier, C., Grabka, M.M. (2015): Große statistische Unsicherheit beim Anteil der TopVermögenden in Deutschland. Wochenbericht des DIW, 7/2015, 123-133.

Wolff, E.N. (1996): International Comparisons of Wealth Inequality, Review of Income and Wealth, 42(4), 433-451.

Wolff, E.N. (2005): Is the Equalizing Effect of Retirement Wealth Wearing Off?, Economics Working Paper Archive wp_420, Levy Economics Institute. 
Wolff, E.N. (2014): Household Wealth Trends in the United States, 1983-2010. Oxford Review of Economic Policy, 30(1), 21-43.

Wolff, E.N. (2015a): U.S. Pensions in the 2000s: The Lost Decade?, Review of Income and Wealth, 61, 599-629.

Wolff, E.N. (2015b): Inheriting Wealth in America: Future Boom or Bust?, Oxford: Oxford University Press.

Wolff, E.N., Marley, M. (1989): Long-Term Trends in U.S. Wealth Inequality: Methodological Issues and Results, NBER Chapters, in: The Measurement of Saving, Investment, and Wealth, 765-844.

Wolff, E.N., Zacharias, A. (2009): Household wealth and the measurement of economic wellbeing in the United States, The Journal of Economic Inequality, 7, 83-115. 


\section{Appendix}

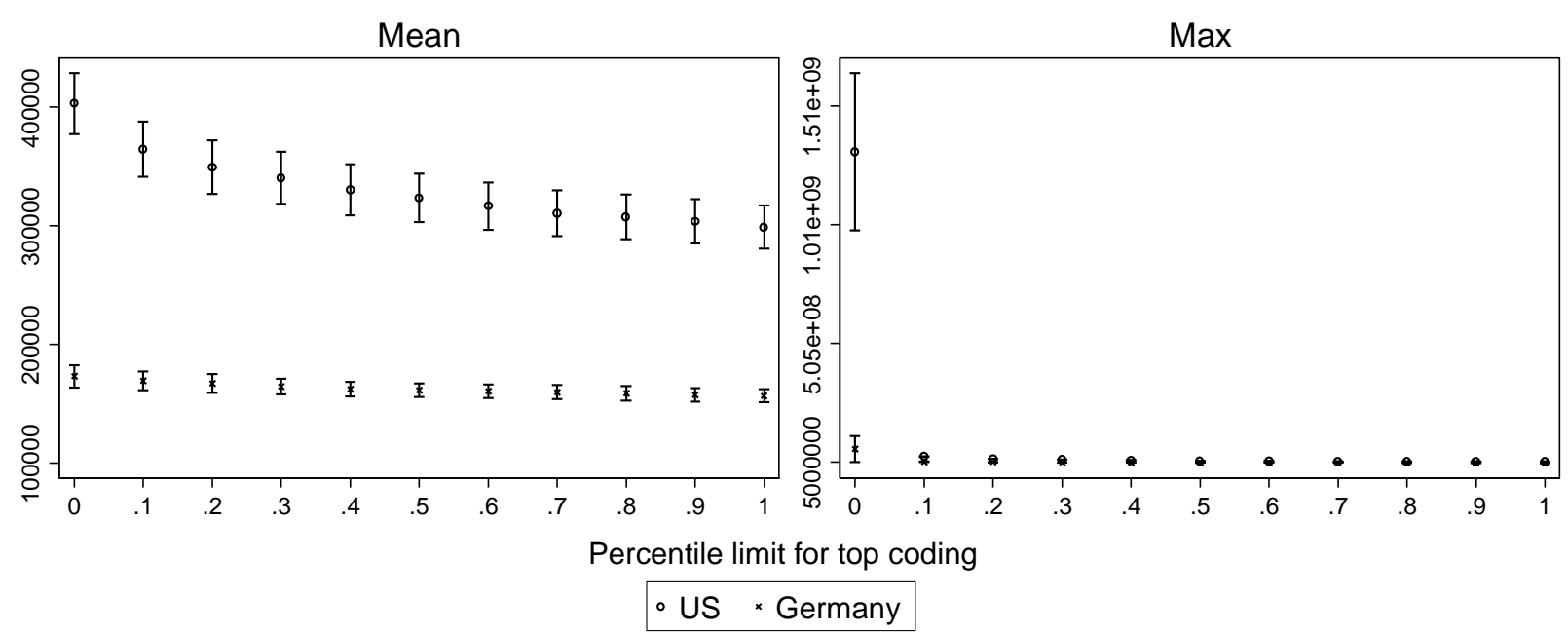

Note: All results based on multiple imputations, bootstrap 95\% confidence interval indicated by bars. Source: SCF 2013 and SOEP v30/v31, own calculations.

Figure A1. Effect of top trimming on mean and maxima of net worth 

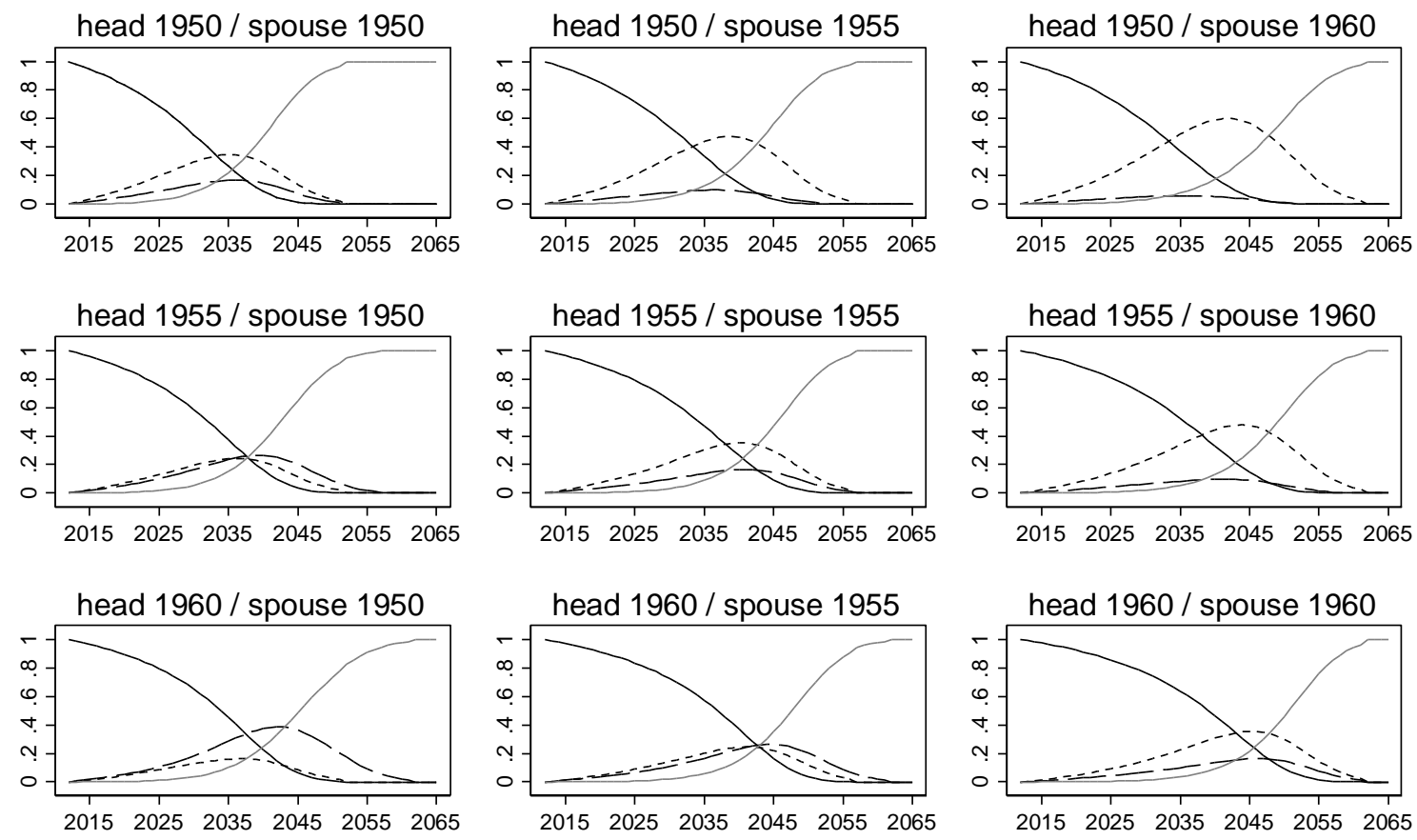

Joint survival - - Surviving head -...-.- Surviving spouse

Both dead

Figure A2. Exemplary household survival rates for Germany 

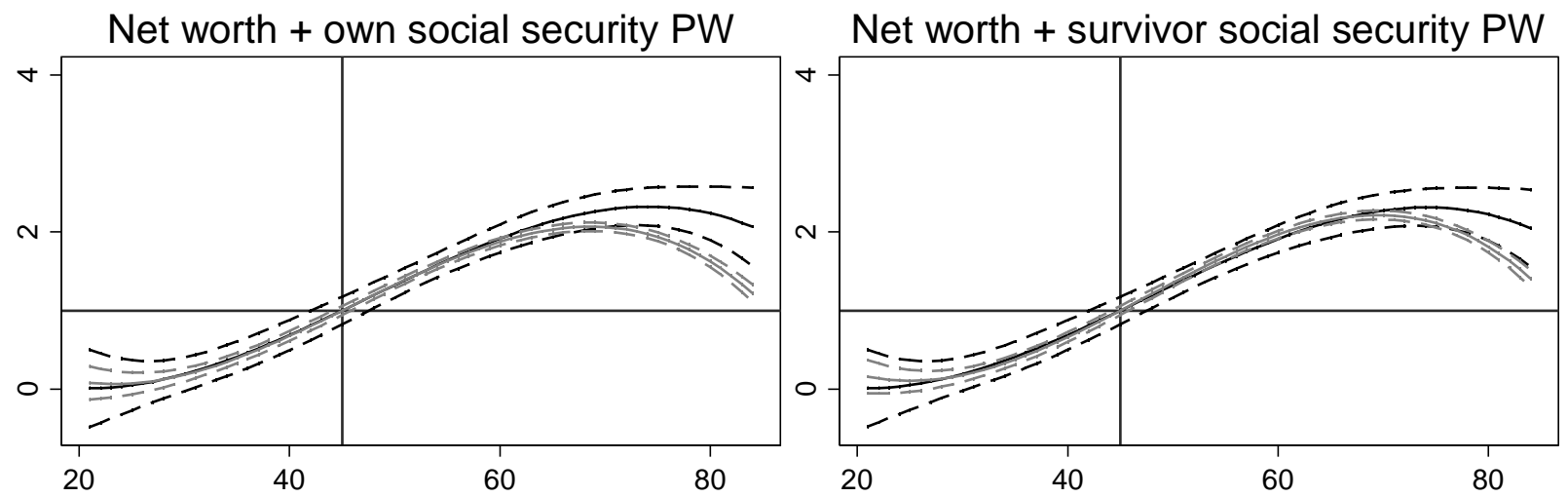

Net worth + occupational and private PW

Total pension wealth
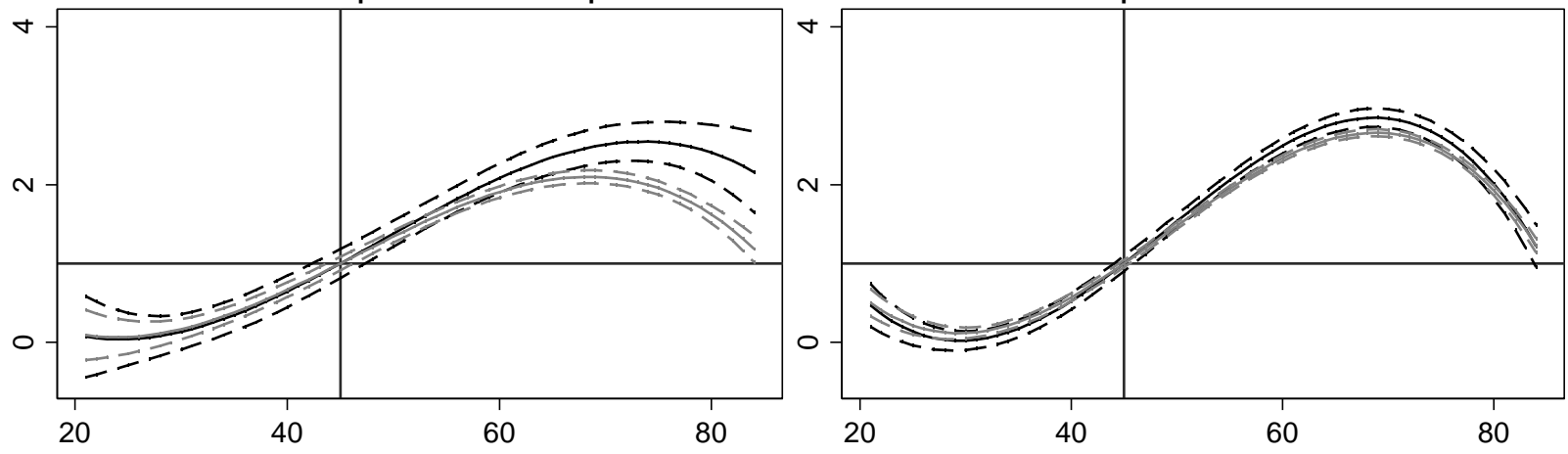

United States

Germany

Note: Sample is top trimmed at 99.9 percent. All results based on multiple imputations.

Dashed lines represent 95\% confidence bands. Source: SCF 2013 and SOEP v30/v31, own calculations.

Figure A3. Normalized age-wealth profiles 
Table A1. Pension benefits in the social-security system by beneficiary type, 2014

\begin{tabular}{|c|c|c|}
\hline Type of Beneficiary & $\begin{array}{c}\text { Number of } \\
\text { Beneficiaries (1000s) }\end{array}$ & $\begin{array}{c}\text { Average Monthly } \\
\text { Benefit (in US\$) }\end{array}$ \\
\hline All Beneficiaries & 58,575 & 1,188 \\
\hline I. Old-Age and Survivors' & & \\
\hline Insurance & 47,604 & 1,232 \\
\hline a. Retired workers & 38,515 & 1,300 \\
\hline b. Spouses of retired workers & 2,294 & 655 \\
\hline 2. Survivor benefits & 6,158 & 1,086 \\
\hline a. Nondisabled widow(er)s & 3,853 & 1,250 \\
\hline b. Disabled widow(er)s & 258 & 714 \\
\hline 3. Disability Insurance & 10,971 & 997 \\
\hline a. Disabled workers & 8,954 & 1,146 \\
\hline b. Spouses of disabled & & \\
\hline workers & 153 & 308 \\
\hline
\end{tabular}


Table A2. GE2-coefficient by wealth aggregate

\begin{tabular}{|c|c|c|c|c|c|c|}
\hline Wealth aggregate & \multicolumn{2}{|c|}{ Total population } & \multicolumn{2}{|c|}{$\begin{array}{c}\text { Total population, bottom } \\
\text { coding at } 0\end{array}$} & \multicolumn{2}{|c|}{$\begin{array}{l}\text { Population with positive } \\
\text { wealth component }\end{array}$} \\
\hline \multicolumn{7}{|c|}{ United States } \\
\hline Net worth & 8.208 & $(0.325)$ & 7.563 & $(0.281)$ & 5.387 & $(0.238)$ \\
\hline $\begin{array}{l}\text { Net worth + social } \\
\text { security pension } \\
\text { wealth without } \\
\text { survivor benefits }\end{array}$ & 4.140 & (0.229) & 3.871 & $(0.204)$ & 3.735 & $(0.201)$ \\
\hline $\begin{array}{l}\text { Net worth }+ \text { total } \\
\text { social security pension } \\
\text { wealth }\end{array}$ & 3.971 & $(0.224)$ & 5.100 & $(0.231)$ & 3.598 & $(0.197)$ \\
\hline $\begin{array}{l}\text { Net worth }+ \\
\text { occupational and } \\
\text { private pension } \\
\text { wealth }\end{array}$ & 5.136 & $(0.242)$ & 4.842 & $(0.219)$ & 3.777 & (0.195) \\
\hline Augmented wealth & 3.088 & (0.187) & 2.936 & $(0.172)$ & 2.843 & $(0.170)$ \\
\hline \multicolumn{7}{|c|}{ Germany } \\
\hline Net worth & 2.476 & $(0.271)$ & 2.325 & $(0.266)$ & 1.520 & $(0.225)$ \\
\hline $\begin{array}{l}\text { Net worth + social } \\
\text { security pension } \\
\text { wealth without } \\
\text { survivor benefits }\end{array}$ & 0.788 & $(0.144)$ & 0.759 & $(0.142)$ & 0.737 & $(0.141)$ \\
\hline $\begin{array}{l}\text { Net worth }+ \text { total } \\
\text { social security pension } \\
\text { wealth }\end{array}$ & 0.721 & $(0.137)$ & 1.080 & $(0.180)$ & 0.674 & $(0.133)$ \\
\hline $\begin{array}{l}\text { Net worth }+ \\
\text { occupational and } \\
\text { private pension } \\
\text { wealth }\end{array}$ & 1.690 & $(0.186)$ & 1.622 & $(0.183)$ & 1.227 & $(0.165)$ \\
\hline Augmented wealth & 0.664 & $(0.112)$ & 0.646 & (0.110) & 0.634 & (0.109) \\
\hline
\end{tabular}


Table A3. Factor decomposition using the GE2 coefficient

\begin{tabular}{|c|c|c|c|c|c|}
\hline \multirow{2}{*}{ Wealth aggregate } & \multicolumn{3}{|c|}{ Components } & \multicolumn{2}{|c|}{ Contribution } \\
\hline & $\rho_{f}$ & $s_{f}$ & $G E(2)_{f}$ & $A_{f}$ & $a_{f}$ \\
\hline \multicolumn{6}{|c|}{ United States } \\
\hline Net worth & 0.961 & 0.517 & 8.209 & 2.500 & 80.96 \\
\hline TNet wortn & (0.029) & $(0.042)$ & $(0.325)$ & (0.182) & $(5.31)$ \\
\hline $\begin{array}{l}\text { Social security } \\
\text { pension wealth }\end{array}$ & 0.378 & 0.229 & 0.345 & 0.089 & 2.90 \\
\hline $\begin{array}{l}\text { without survivor } \\
\text { benefits }\end{array}$ & $(0.052)$ & $(0.033)$ & (0.039) & $(0.025)$ & $(1.92)$ \\
\hline Social security & 0.363 & 0.019 & 1.056 & 0.012 & 0.40 \\
\hline $\begin{array}{l}\text { pension wealth from } \\
\text { survivor benefits }\end{array}$ & $(0.058)$ & $(0.010)$ & $(0.076)$ & $(0.012)$ & $(0.70)$ \\
\hline Occupational and & 0.610 & 0.235 & 3.712 & 0.486 & 15.74 \\
\hline $\begin{array}{l}\text { private pension } \\
\text { wealth }\end{array}$ & $(0.067)$ & $(0.033)$ & $(0.266)$ & $(0.091)$ & $(5.13)$ \\
\hline $\begin{array}{l}\text { Total inequality } \\
\text { (augmented wealth) }\end{array}$ & & & 3.088 & 3.088 & 100.00 \\
\hline \multicolumn{6}{|c|}{ Germany } \\
\hline Net worth & 0.886 & 0.386 & 2.476 & 0.439 & 65.97 \\
\hline Net wortn & $(0.047)$ & $(0.041)$ & $(0.271)$ & (0.115) & $(8.76)$ \\
\hline $\begin{array}{l}\text { Social security } \\
\text { pension wealth }\end{array}$ & 0.402 & 0.377 & 0.373 & 0.075 & 11.41 \\
\hline $\begin{array}{l}\text { without survivor } \\
\text { benefits }\end{array}$ & $(0.076)$ & $(0.034)$ & $(0.041)$ & $(0.027)$ & $(5.28)$ \\
\hline Social security & 0.126 & 0.046 & 2.514 & 0.008 & 1.14 \\
\hline $\begin{array}{l}\text { pension wealth from } \\
\text { survivor benefits }\end{array}$ & $(0.049)$ & $(0.017)$ & $(0.135)$ & $(0.012)$ & $(1.75)$ \\
\hline Occupational and & 0.573 & 0.191 & 2.553 & 0.142 & 21.49 \\
\hline $\begin{array}{l}\text { private pension } \\
\text { wealth }\end{array}$ & $(0.080)$ & $(0.031)$ & $(0.124)$ & $(0.038)$ & (6.98) \\
\hline $\begin{array}{l}\text { Total inequality } \\
\text { (augmented wealth) }\end{array}$ & & & 0.664 & 0.664 & 100.000 \\
\hline
\end{tabular}

Note: Sample is top-trimmed at 99.9 percent. All results based on multiple imputations, bootstrap standard errors accounting for multiple imputation in parentheses.

Source: SCF 2013 and SOEP v30/v31, own calculations.

$\mathrm{GE}(2)$ decomposition by $f=1, \ldots F$ factors:

$$
G E(2)=\sum_{f=1}^{F} \rho_{f} \times s_{f} \sqrt{G E(2) \times G E(2)_{f}}=\sum_{f=1}^{F} A_{f}=\sum_{f=1}^{F} a_{f} \times G E(2)
$$

Where $G E(2)$ is half-squared coefficient of variation, $\rho_{f}$ is the correlation between wealth component $f$ and total wealth, and $G E(2)_{f}$ is the coefficient of component $f$ and $s_{f}$ the share of component $f$ on 
total wealth. $A_{f}$ is the absolute contribution to overall inequality and $a_{f}=\frac{A_{f}}{G E(2)}$ the relative contribution.

Table A4. Basic descriptive statistics by wealth aggregate for per capita distributions

\begin{tabular}{|c|c|c|c|c|c|}
\hline Wealth aggregate & $\begin{array}{c}\text { Mean } \\
(\mathrm{SE})\end{array}$ & P25 & P50 & P75 & $\begin{array}{c}\text { Fraction }>0 \\
\text { (SE) }\end{array}$ \\
\hline \multicolumn{6}{|c|}{ United States } \\
\hline Net worth & $\begin{array}{c}130,708 \\
(2,275)\end{array}$ & 0 & 10,000 & 67,500 & $\begin{array}{l}70.59 \\
(0.34)\end{array}$ \\
\hline $\begin{array}{l}\text { Social security pension } \\
\text { wealth }\end{array}$ & $\begin{array}{l}62,697 \\
(, 410)\end{array}$ & 18,612 & 38,941 & 84,257 & $\begin{array}{l}96.89 \\
(0.14)\end{array}$ \\
\hline $\begin{array}{l}\text { Social security pension } \\
\text { wealth without survivor } \\
\text { benefit }\end{array}$ & $\begin{array}{r}57,955 \\
(, 383)\end{array}$ & 16,178 & 35,438 & 77,751 & $\begin{array}{l}96.89 \\
(0.14)\end{array}$ \\
\hline $\begin{array}{l}\text { Social security pension } \\
\text { wealth from survivor } \\
\text { benefit }\end{array}$ & $\begin{array}{l}4,742 \\
(, 044)\end{array}$ & 0 & 2,276 & 6,238 & $\begin{array}{l}69.67 \\
(0.32)\end{array}$ \\
\hline $\begin{array}{l}\text { Occupational and } \\
\text { private Pension wealth }\end{array}$ & $\begin{array}{l}59,542 \\
(0,913)\end{array}$ & 0 & 3,000 & 44,667 & $\begin{array}{l}61.09 \\
(0.39)\end{array}$ \\
\hline Augmented wealth & $\begin{array}{l}252,947 \\
(3,000)\end{array}$ & 21,497 & 76,995 & 229,602 & $\begin{array}{l}95.83 \\
(0.16)\end{array}$ \\
\hline \multicolumn{6}{|c|}{ Germany } \\
\hline Net worth & $\begin{array}{l}93,246 \\
(1,406)\end{array}$ & 0 & 27,587 & 109,040 & $\begin{array}{l}73.42 \\
(0.27)\end{array}$ \\
\hline $\begin{array}{l}\text { Social security pension } \\
\text { wealth }\end{array}$ & $\begin{array}{c}102,389 \\
(, 556)\end{array}$ & 25,278 & 67,545 & 159,990 & $\begin{array}{l}95.33 \\
(0.10)\end{array}$ \\
\hline $\begin{array}{l}\text { Social security pension } \\
\text { wealth without survivor } \\
\text { benefit }\end{array}$ & $\begin{array}{l}91,224 \\
(, 501)\end{array}$ & 24,075 & 60,488 & 140,411 & $\begin{array}{l}95.15 \\
(0.11)\end{array}$ \\
\hline $\begin{array}{l}\text { Social security pension } \\
\text { wealth from survivor } \\
\text { benefit }\end{array}$ & $\begin{array}{l}11,165 \\
(, 147)\end{array}$ & 0 & 0 & 0 & $\begin{array}{l}24.53 \\
(0.22)\end{array}$ \\
\hline $\begin{array}{l}\text { Occupational and } \\
\text { private Pension wealth }\end{array}$ & $\begin{array}{l}46,044 \\
(0,559)\end{array}$ & 0 & 8,379 & 38,983 & $\begin{array}{l}70.11 \\
(0.23)\end{array}$ \\
\hline Augmented wealth & $\begin{array}{c}241,679 \\
(1,663)\end{array}$ & 61,022 & 159,529 & 319,216 & $\begin{array}{l}98.73 \\
(0.06)\end{array}$ \\
\hline
\end{tabular}

Note: Sample is top-trimmed at 99.9 percent. All results based on multiple imputations, bootstrap standard errors accounting for multiple imputation in parentheses. Nonlinear estimates (P25, p50, P75) based on first imputation only. Source: SCF 2013 and SOEP v30/v31, own calculations. 
Table A5. Gini coefficient by wealth aggregate for per capita distributions

\begin{tabular}{|c|c|c|c|c|c|c|}
\hline Wealth aggregate & \multicolumn{2}{|c|}{ Total population } & \multicolumn{2}{|c|}{$\begin{array}{c}\text { Total population, bottom } \\
\text { coding at } 0\end{array}$} & \multicolumn{2}{|c|}{$\begin{array}{l}\text { Population with positive } \\
\text { wealth component }\end{array}$} \\
\hline \multicolumn{7}{|c|}{ United States } \\
\hline Net worth & 0.894 & $(0.034)$ & 0.857 & $(0.030)$ & 0.804 & $(0.034)$ \\
\hline $\begin{array}{l}\text { Net worth + social } \\
\text { security pension } \\
\text { wealth without }\end{array}$ & 0.725 & $(0.038)$ & 0.615 & $(0.038)$ & 0.701 & $(0.038)$ \\
\hline $\begin{array}{l}\text { Net worth + social } \\
\text { security pension } \\
\text { wealth including } \\
\text { survivor benefits }\end{array}$ & 0.718 & $(0.038)$ & 0.607 & $(0.038)$ & 0.696 & $(0.038)$ \\
\hline $\begin{array}{l}\text { Net worth }+ \\
\text { occupational and } \\
\text { private pension } \\
\text { wealth }\end{array}$ & 0.833 & $(0.033)$ & 0.812 & $(0.032)$ & 0.766 & $(0.035)$ \\
\hline Augmented wealth & 0.714 & $(0.036)$ & 0.623 & $(0.036)$ & 0.696 & $(0.036)$ \\
\hline \multicolumn{7}{|c|}{ Germany } \\
\hline Net worth & 0.775 & $(0.043)$ & 0.748 & $(0.038)$ & 0.647 & $(0.044)$ \\
\hline $\begin{array}{l}\text { Net worth + social } \\
\text { security pension } \\
\text { wealth without } \\
\text { survivor benefits }\end{array}$ & 0.528 & $(0.040)$ & 0.477 & $(0.037)$ & 0.511 & (0.039) \\
\hline $\begin{array}{l}\text { Net worth + social } \\
\text { security pension } \\
\text { wealth including } \\
\text { survivor benefits }\end{array}$ & 0.518 & (0.039) & 0.468 & $(0.036)$ & 0.502 & $(0.038)$ \\
\hline $\begin{array}{l}\text { Net worth }+ \\
\text { occupational and } \\
\text { private pension } \\
\text { wealth }\end{array}$ & 0.722 & $(0.038)$ & 0.707 & $(0.035)$ & 0.641 & $(0.038)$ \\
\hline Augmented wealth & 0.516 & (0.037) & 0.464 & $(0.034)$ & 0.505 & $(0.036)$ \\
\hline
\end{tabular}




\section{Basic rules for the determination of survivor civil servant pensions}

The living basis for bereaved partner ${ }^{42}$ of a civil servant is determined based on the following basic rules: ${ }^{43}$

1. The marriage must have lasted for at least 12 months for marriages after Dec. 31, 2001 otherwise for three months. If the civil servant was above age 65 at the beginning of the marriage and the marriage was childless, no survivor pension is granted.

2. A widow(er) pension is granted if the deceased partner was a civil servant for at least five years.

3. The widow(er) pension amounts to $60 \%$ (55\%) of the pension of the deceased partner for survivors born before (after) Dec. 31, 1961.

4. The level of the widow(er) pension depends on the income situation of the widow(er) with particular deduction rules applying. ${ }^{44}$

\footnotetext{
${ }^{42} \mathrm{~A}$ widow(er) pension was received by about 311,000 individuals age 65 and older (BMAS 2012a). Due to data limitations and consistency, again we refrain from modeling orphan pensions.

${ }^{43}$ Exemptions from the general rules exist.

${ }^{44}$ Two cases must be distinguished: Case 1: widow(er) is retired and receives a statutory PAYG pension: According to $\S 55$ (3) 2 of Germany's Civil Service Benefits Act (Beamtenversorgungsgesetz, BeamtVG), the full widow(er) pension is granted. Case 2: widow(er) is retired and receives a civil servant pension: According to $\S 55$ (2) 2 the complete widow(er) pension is granted, but the own civil servant pension is reduced. The deduction of the own pension is the sum of the widow(er)'s own pension plus her widower pension minus the maximum pension entitlement of the deceased person. The maximum entitlement of the deceased person is 0.75 times her pay grade.
} 